\title{
ATIVIDADE DAS ENZIMAS REDUTASE DO NITRATO E GLUTAMINA SINTETASE EM CAFEEIRO ARÁBICA
}

\author{
JOSÉ FERNANDES DE ANDRADE NETTO
}

Dissertação apresentada à Escola Superior de Agricultura "Luiz de Queiroz", Universidade de São Paulo, para obtenção do título de Mestre em Agronomia, Área de Concentração: Fitotecnia.

\author{
PIR A C I C A B A \\ Estado de São Paulo - Brasil \\ Fevereiro - 2005
}




\title{
ATIVIDADE DAS ENZIMAS REDUTASE DO NITRATO E GLUTAMINA SINTETASE EM CAFEEIRO ARÁBICA
}

\author{
JOSÉ FERNANDES DE ANDRADE NETTO \\ Engenheiro Agrônomo
}

Orientador: Prof. Dr. JOSÉ LAÉRCIO FAVARIN

Dissertação apresentada à Escola Superior de Agricultura "Luiz de Queiroz", Universidade de São Paulo, para obtenção do título de Mestre em Agronomia, Área de Concentração: Fitotecnia.

\author{
PIR A C I C A B A \\ Estado de São Paulo - Brasil \\ Fevereiro - 2005
}


Dados I nt ernacionai s de Cat al ogação na Publi cação ( CI P) DI VI SÃO DE BI BLI OTECA E DOCUMENTAÇÃO - ESALQI USP

Andrade Netto, José Fernandes de

Atividade das enzimas redutase do nitrato e glutamina sintetase em cafeeiro arábica /

José Fernandes de Andrade Netto. - - Piracicaba, 2005.

60 p. : il.

Dissertação (Mestrado) - - Escola Superior de Agricultura Luiz de Queiroz, 2005.

Bibliografia.

1. Café 2. Condutância estomática 3. Fotossíntese 4. Radiação fotossintética ativa 5. Temperatura atmosférica 6 . Transpiração vegetal I. Título

CDD 633.73 
Aos meus pais, CARLOS e GLÓRIA, OFEREÇO

À minha querida esposa DÉBORA e à nossa amada filha CAROLINA, 


\section{AGRADECIMENTOS}

À Deus por permitir a conclusão deste trabalho, por estar presente em todos os momentos da minha vida.

Ao Professor José Laércio Favarin, pela orientação científica, paciência e amizade.

Ao Professor Luiz Antonio Gallo pelo apoio apresentado em todos os momentos, pela grande generosidade, pelos valiosos ensinamentos, além da preciosa amizade.

Ao Biólogo Enio Tiago de Oliveira pelos ensinamentos, apoio durante a fase experimental e amizade.

Ao amigo Janilson Pinheiro de Assis pelo apoio profissional e pessoal e pela grande amizade.

Aos colegas Shoey Kanashiro, Adriana Teramoto e Sergio K. Tanioka, pela amizade e companheirismo.

Aos funcionários do Departamento de Produção Vegetal, Tino, Marcelo, Osmair e Tanaka, pelo suporte técnico dado ao trabalho.

À Escola Superior de Agricultura "Luiz de Queiroz", Universidade de São Paulo, pela oportunidade de crescimento pessoal e profissional.

À Universidade Estadual do Sudoeste da Bahia - UESB, pela concessão da Bolsa de Estudos. 


\section{SUMÁRIO}

Página

LISTA DE FIGURAS .................................................................... viii

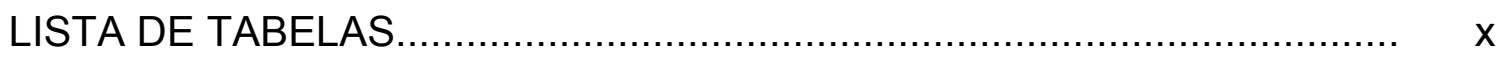

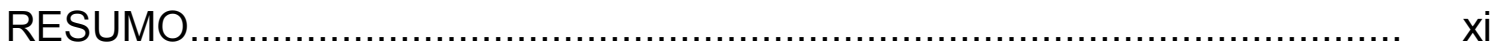

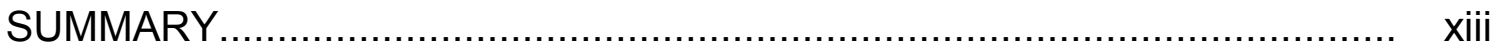

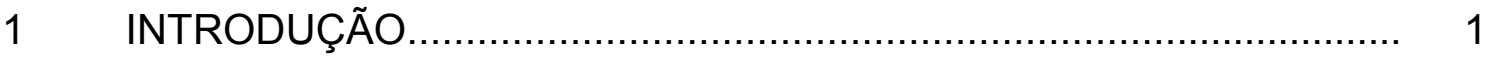

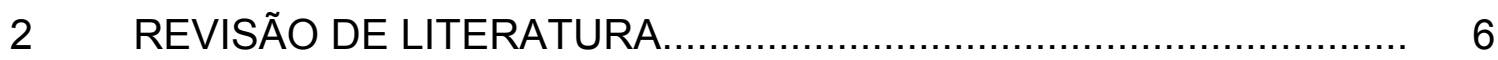

2.1 Classificação taxonômica do cafeeiro........................................... 6

2.2 Aspectos ecofisiológicos do cafeeiro arábica.................................... 6

2.3 Assimilação de nitrogênio pelas plantas........................................... 7

2.4 Características da enzima redutase do nitrato - RN...................... 8

2.5 Regulação da atividade da redutase do nitrato - RN........................ 9

2.6 Redutase do nitrato e luminosidade em café.................................... 12

2.7 Características da glutamina sintetase - GS................................. 14

3 MATERIAL E MÉTODOS ........................................................ 18

3.1 Localização do experimento..................................................... 18

3.2 Formação das mudas de café..................................................... 18

3.3 Tratamentos utilizados e condução das plantas................................ 19

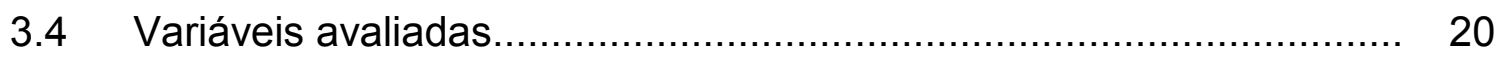

3.5 Preparo dos extratos para análise das atividades enzimáticas.......... 21 
3.5.1 Atividade da redutase do nitrato (RN) .................................... 21

3.5.2 Atividade da glutamina sintetase (GS)........................................ 23

3.6 Avaliações ecofisiológicas......................................................... 23

3.7 Determinação do teor de proteína total solúvel (PTS) .................... 24

3.8 Análise vegetativa............................................................... 25

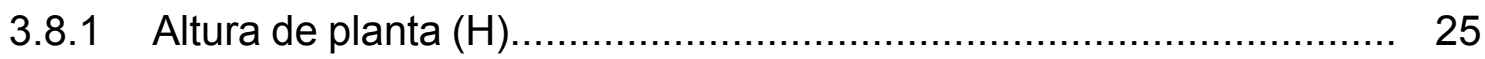

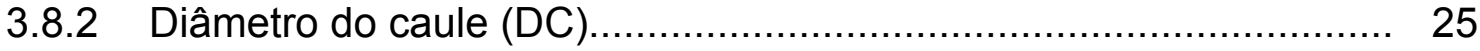

3.8.3 Número de ramos plagiotrópicos (NRP) ..................................... 25

3.8.4 Número de folhas da planta (NF) ............................................ 25

3.8.5 Matéria seca de folhas (MS) ............................................. 26

3.9 Análise química de folhas...................................................... 26

3.9.1 Preparo do material vegetal para análise...................................... 26

3.9.2 Determinação de macro e micronutrientes.................................... 27

3.10 Delineamento experimental..................................................... 29

$4 \quad$ RESULTADOS E DISCUSSÃO............................................... 30

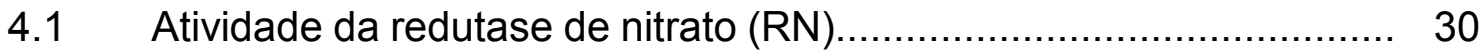

4.2 Atividade da glutamina sintetase (GS) .................................... 34

$4.3 \quad$ Atributos ecofisiológicos....................................................... 38

4.4 Resultados da análise química foliar......................................... 42

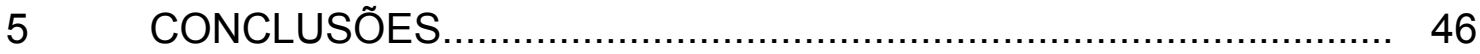

REFERÊNCIAS BIBLIOGRÁFICAS.................................................... 47 


\section{LISTA DE FIGURAS}

Página

1 Método de coleta de discos foliares para determinação da atividade das enzimas redutase do nitrato e glutamina sintetase em folhas de C. arabica cv Obatã IAC 1669-20 cultivadas a pleno sol e a meia sombra às 7:00 $h, \quad 12: 00 \quad h, \quad 17: 00 \quad h \quad e$ 22:00h

2 Medidor portátil modelo LI - 6400 utilizado para determinar os atributos ecofisiológicos como a temperatura atmosférica (Ta), temperatura foliar (Tf), condutância estomática (gs), taxa de transpiração $(\mathbf{E})$, taxa de fotossíntese líquida $(\mathbf{A})$ e radiação

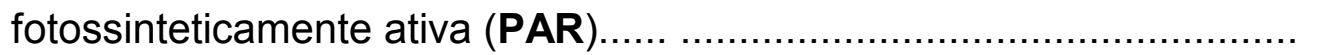

3 Mudas de cafeeiro Coffea arabica L. cv Obatã 1669-20 cultivadas a pleno sol e a meia sombra............................................................ 26

4 Médias da atividade da redutase do nitrato (RN) em mudas de Coffea arabica L. cv Obatã IAC 1669-20 cultivadas a pleno sol e a meia sombra às 7:00 $h, \quad 12: 00 \quad h, \quad 17: 00 \quad h \quad e$ 22:00h. 
5 Médias da atividade da glutamina sintetase (GS) em mudas de Coffea arabica L. cv Obatã IAC 1669-20 cultivadas a pleno sol e a meia sombra às 7:00 $h, 12: 00 h, \quad 17: 00 \quad h \quad e$ 22:00h.

6 Médias de proteína total solúvel (PTS) em mudas de Coffea arabica L. cv Obatã IAC 1669-20 cultivadas a pleno sol e a meia sombra às 7:00 h, 12:00 h, 17:00 h e 22:00 h

7 Médias da taxa de fotossíntese líquida (A) em mudas de Coffea arabica L. cv Obatã IAC 1669-20 cultivadas a pleno sol e a meia sombra às 7:00 h, 12:00 h e 17:00 h

8 Médias da condutância estomática (gs) em mudas de Coffea arabica L. cv Obatã IAC 1669-20 cultivadas a pleno sol e a meia sombra às 7:00 h, 12:00 e 17:00 h

9 Médias da taxa de transpiração (E) em mudas de Coffea arabica L. cv Obatã IAC 1669-20 cultivadas a pleno sol e a meia sombra às 7:00 h, 12:00 h e 17:00 h.

10 Médias do diâmetro de caule (DC); altura da planta (H); número de folhas (NF) e número de ramos plagiotrópicos (NRP) de mudas de Coffea arabica L. cv Obatã IAC 1669-20 cultivadas a pleno sol e a meia sombra.

11 Médias da matéria seca de folhas (MS) de Coffea arabica L. cv Obatã IAC 1669-20 cultivadas a pleno sol e a meia sombra. 


\section{LISTA DE TABELAS}

1 Médias da taxa de fotossíntese líquida (A), condutância estomática (gs), taxa de transpiração (E), temperatura atmosférica (Ta), temperatura foliar (Tf) e radiação fotossinteticamente ativa (PAR) em mudas de Coffea arabica L. cv Obatã 1669-20 cultivadas a pleno sol

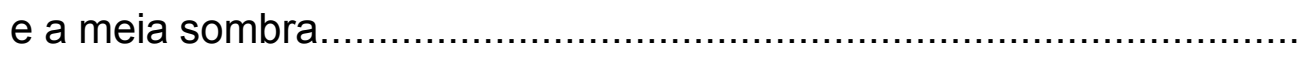

2 Resultados da análise química de amostras foliares utilizadas na determinação da atividade da redutase do nitrato em mudas de Coffea arabica L. cv Obatã IAC 1669-20 cultivadas a pleno sol e a

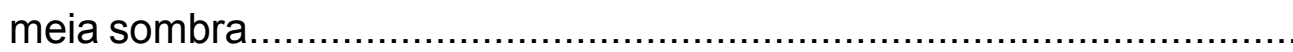




\title{
ATIVIDADE DAS ENZIMAS REDUTASE DO NITRATO E GLUTAMINA SINTETASE EM CAFEEIRO ARÁBICA
}

\author{
Autor: JOSÉ FERNANDES DE ANDRADE NETTO \\ Orientador: Prof. Dr. JOSÉ LAÉRCIO FAVARIN
}

\section{RESUMO}

O objetivo deste trabalho foi avaliar a atividade das enzimas redutase do nitrato (RN) e glutamina sintetase (GS) em mudas de Coffea arabica L cv Obatã IAC 1669-20 em função dos atributos ecofisiológicos. O experimento foi conduzido em casa de vegetação no Laboratório de Biotecnologia Agrícola do Departamento de Ciências Biológicas da Escola Superior de Agricultura "Luiz de Queiroz", Universidade de São Paulo. Para a realização do experimento adotou-se o delineamento inteiramente casualizado com dois tratamentos: T1 (100\% de luz) e T2 (50\% de luz) e cinco repetições. As determinações das atividades enzimáticas foram feitas às 07:00 h; 12:00 h; 17:00 h e 22:00 h, bem como dos atributos ecofisiológicos: temperatura atmosférica; temperatura foliar; radiação fotossinteticamente ativa; condutância estomática; taxa de fotossíntese líquida; taxa de transpiração e proteína total solúvel. O nível de exposição à luminosidade altera a atividade da redutase do nitrato (RN), cujo valor foi menor nas plantas a pleno sol às $12: 00 \mathrm{~h}$ e 17:00 h. A saturação 
lumínica e a maior temperatura foliar em relação ao ambiente, às 12:00 h, diminuiu as trocas gasosas ( $\mathrm{CO}_{2}$ e vapor d'água) e a atividade da $\mathbf{R N}$. Ao longo do período luminoso, independentemente do nível de exposição à luminosidade, decresceu a atividade da glutamina sintetase (GS). A disponibilidade de amônio proveniente da ação da RN no período noturno elevou a atividade da GS, enquanto a fotorrespiração, por hipótese, forneceu o substrato $\left(\mathrm{NH}_{4}{ }^{+}\right)$para a atividade dessa enzima (GS) nas plantas a pleno sol ao meio dia. A inibição da redutase do nitrato $(\mathbf{R N})$ no cafeeiro proporcionada pela fotorrespiração se dá, por hipótese, em resposta a produção de glutamina por meio da atividade da glutamina sintetase (GS).

Palavras - Chave: Coffea arabica L., condutância estomática, taxa de fotossíntese líquida, taxa de transpiração, radiação fotossinteticamente ativa, temperatura atmosférica e foliar 


\title{
ACTIVITY OF THE NITRATE REDUCTASE AND GLUTAMINE SYNTHETASE ENZYMES IN ARABIC COFFEE
}

\author{
Author: JOSÉ FERNANDES DE ANDRADE NETTO \\ Adviser: Prof. Dr. JOSÉ LAÉRCIO FAVARIN
}

\section{SUMMARY}

The aim of this work was to evaluate the activity of the enzymes nitrate reductase (RN) and glutamine synthetase (GS) in seedlings of Coffea arabica $L$ cv Obatã IAC 1669 - 20 in face of the eco-physiological attributes. The experiment was conducted in a greenhouse at the Laboratory of Agricultural Biotechnology in the Biological Science Department of the Superior School of Agriculture "Luiz de Queiroz", São Paulo University. The completely randomized experimental design was utilized for the experiment with two treatments: T1 ( $100 \%$ of light) e T2 (50\% of light), each on made up of five replicates. The enzymatic activities and eco-physiological attributes determinations such as air temperature, leaf temperature, photosynthetically active radiation, stomatal conductance, net photosynthesis rate, transpiration rate and total soluble protein were made at 7:00 AM, 12:00 AM, 5:00 PM and 10:00 PM. The level of radiation exposition changes the nitrate reductase activity, whose value was smaller in plants at full sun at 12:00 AM and 5:00 PM. The light saturation and the higher leaf temperature in relation to the environment, at 12:00 AM, reduced the gas 
exchanges ( $\mathrm{CO}_{2}$ and water vapor) and $\mathbf{R N}$ activity. Along the light period, independently of radiation exposition level, the activity of the glutamine synthetase decreased. The availability of ammonium provided by RN during dark period, independently of the treatments, increase the GS activity, while photorespiration, hypothetically, supplied the substrate $\left(\mathrm{NH}_{4}{ }^{+}\right)$to the $\mathbf{G S}$ action in plants under full sun at 12:00 AM. The RN inhibition in coffee plants provides the photorespiration occurred in response to the glutamine production through the GS activity.

Key - words: Coffea arabica L., estomatal conductance, net photosynthesis rate, transpiration rate, photosynthetically active radiation, leaf and air temperature 


\section{INTRODUÇÃO}

No Brasil as cultivares de café foram selecionadas a pleno sol, por isso as mesmas apresentam, potencialmente, adaptações à elevada irradiância (DaMatta \& Rena, 2002). Contudo, a baixa relação entre as clorofilas a e b, característica das plantas de sombra, tem sido mantida nas folhas expostas ao sol (Fahl et al., 1994; DaMatta \& Maestri, 1997). Por isso, o cafeeiro pode ser considerado como uma planta facultativa de sombra, com alta plasticidade às variações de irradiância (DaMatta \& Rena, 2002).

Os mecanismos fisiológicos responsáveis pelas diferenças entre as plantas adaptadas a sombra e ao sol não são bem entendidos. As folhas das espécies de sombra, geralmente, possuem maior quantidade de clorofila com base na massa foliar. $O$ aumento desse pigmento nessas plantas está associado à redução da espessura foliar, aumentando a eficiência na utilização da luz. Em plantas de café a eficiência quântica das folhas sombreadas é, frequentemente, superior àquela verificada nas folhas expostas ao sol (Kozlowski et al., 1991).

O cafeeiro embora possua característica umbrófila, típica de ambiente de sub-boque, apresenta elevada produção quando cultivado ao sol. Em razão dessa característica é comum a fotoinibição provocada pela saturação do aparelho fotossintético sob elevada irradiância (DaMatta \& Maestri, 1997).

As folhas sombreadas são mais eficientes na assimilação do carbono $\left(\mathrm{CO}_{2}\right)$ do que as folhas expostas ao sol, pois nos trópicos a radiação solar, invariavelmente, supera de 3 a 5 vezes o limite de saturação lumínica. Além disso, a temperatura foliar pode alcançar $5^{\circ} \mathrm{C}$ a $20^{\circ} \mathrm{C}$ a mais que a temperatura 
do ar, danificando o tecido foliar. Estudos desenvolvidos por Hernandez et al. (1989) e, recentemente, por Marin et al. (2003), corroboram esta hipótese por meio de medidas de transpiração. Estes autores verificaram que mesmo reduzindo a energia radiante às plantas, por meio do sombreamento, a transpiração diminui cerca de $10 \%$ comparada aos valores determinados nas plantas a pleno sol.

Os vegetais superiores sintetizam os compostos orgânicos a partir da fotossíntese e da absorção de água e de nutrientes minerais absorvidos do solo, incorporando-os em várias substâncias como, por exemplos, os pigmentos ( $\mathrm{N}$ e $\mathrm{Mg}$ ), aminoácidos e proteínas ( $\mathrm{N}$ e S), parede celular (Ca) e nas enzimas nitrogenase (Mo), superóxido dismutase $(\mathrm{Zn}$ e $\mathrm{Cu})$, redutase do nitrato (Mo) e desidrogenase glutâmica $(\mathrm{Cu})$.

O nitrato é a principal forma nitrogenada absorvida pelas plantas, independentemente da natureza química que o nitrogênio é aplicado no solo. $O$ predomínio do nitrato se deve, basicamente, ao $\mathrm{pH}$ da solução, normalmente, próximo da neutralidade, devido à incubação efetuada para a neutralização da acidez ativa e potencial, visando à condução de mudas em recipientes que restringem o volume de solo explorado pelas raízes - como em vasos. Nesta condição, a nitrificação é favorecida e as bactérias nitrosomonas (nitritação, $\mathrm{NO}_{2}{ }^{-}$) e nitrobacter (nitratação, $\mathrm{NO}_{3}{ }^{-}$) transformam as diferentes formas de nitrogênio em nitrato.

Em trabalho realizado por Souza \& Lobato (2002), aplicando nitrogênio

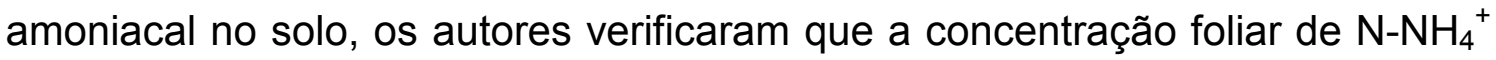
foi detectada nos primeiros cinco dias após o fornecimento do nutriente, apresentando concentrações foliares semelhantes (50\%) entre as formas $\mathrm{N}$ $\mathrm{NH}_{4}{ }^{+}$e N-NO${ }_{3}^{-} 15$ dias após a aplicação. Depois de 25 dias da aplicação $100 \%$ do nitrogênio determinado na planta estava na forma nítrica. Do exposto, verifica-se que na ausência de substâncias que impeçam a nitrificação esse processo é muito rápido, o que explica a absorção de nitrogênio, predominantemente, na forma nítrica. 
As plantas utilizam uma porção significativa das suas reservas de carbono e energia para a assimilação do nitrato $\left(\mathrm{NO}_{3}{ }^{-}\right)$, principal forma de nitrogênio absorvido pelos vegetais, em razão do consumo energético para reduzí-lo a amônio $\left(\mathrm{NH}_{4}{ }^{+}\right)$, forma que é utilizada para incorporar nitrogênio nas estruturas de carbono.

Durante a assimilação do nitrogênio em compostos orgânicos, o nitrato é, primeiramente, reduzido a forma amoniacal por meio de um processo que envolve a participação de duas enzimas - a redutase do nitrato (RN) e a redutase do nitrito (RNi) (Crawford et al., 2000).

A luz e o teor de nitrato são fatores importantes na indução e manutenção da atividade da enzima RN nos tecidos vegetais (Hageman \& Flesher, 1960; Beevers \& Hageman, 1969; Galangau et al., 1988; Vincentz et al., 1993). De acordo com diversos autores a atividade da RN nas folhas de várias espécies, aumenta durante as horas de luz e decresce no escuro (Harper \& Hageman, 1972; Lewis et al., 1982; Hipkin et al., 1984).

Diferente da maioria das espécies vegetais, nas plantas jovens de café as maiores atividades da $\mathbf{R N}$ foliar ocorrem durante o período escuro, diminuindo sua ação na presença de luz (Miranda Neto, 1970; Faleiros et al., 1975; Carvalho, 1975; Cordeiro et al., 1984; Alves et al., 1985). Este comportamento favorece o crescimento das mudas de café, em particular, quando as mesmas são expostas a $50 \%$ de luz, conforme estudos realizados por Silveira \& Maestri (1973) e Paiva (2001). Esta é, certamente, a razão porque as mudas de café são formadas em viveiros expostas a $50 \%$ de luz (meia sombra).

A quantidade de carboidratos, a luminosidade disponível e outros fatores ambientais ativam a fosfatase, enzima responsável pela desfosforilação de vários resíduos de serina na proteína da redutase do nitrato e, com isso, favorece a ação enzimática da RN. A falta de luz (escuro) e de magnésio estimulam a fosforilação dos resíduos de serina os quais interagem com uma 
proteína inibidora, resultando na desativação da redutase do nitrato (RN) (Kaizer et al., 1999).

Carelli et al. (1990) estudaram o efeito da quantidade de luz (50\% e $100 \%$ ) e o fornecimento de nitrogênio sobre a ação da enzima RN, bem como o teor de nitrato e a quantidade de açúcares nas folhas de plantas jovens de café (Coffea arabica L.). Os autores verificaram que a atividade da RN foi menor nas folhas de plantas a pleno sol do que nas folhas das plantas a meia sombra (50\% de luz). A taxa de transpiração e os teores de açúcares e de nitrato aumentaram nas plantas expostas ao sol, indicando que a disponibilidade de substrato (nitrato) e energia (carboidrato) não limita a assimilação redutiva do nitrogênio. Este comportamento não foi, devidamente, explicado diferindo daquele que é observado na maioria das plantas.

Trabalhos recentes demonstraram que um metabólito poderia atuar como uma molécula sinalizadora e, assim, controlaria a atividade da RN. Crawford et al. (2000) acreditam que o aminoácido glutamina seria esse metabólito, devido à relação inversa entre a concentração da glutamina foliar e a atividade da RN. Para Stitt et al. (2002) a glutamato sintase (GOGAT) e ou glutamato desidrogenase $(\mathrm{GDH})$ representam uma posição importante para a regulação do metabolismo do amônio.

Garbayo et al. (2002) trabalhando com células de microalga Chlamydomonas reinhardtii constataram inibição no consumo de nitrato, o qual foi substituído por nitrito. O consumo seqüencial de nitrito seguido do nitrato foi observado após ter sido consumido, praticamente, o amônio disponível. Este comportamento foi explicado com base na acumulação de amônio produzido pela fotorrespiração. Os autores sugeriram que uma alta proporção entre $\mathrm{O}_{2} \mathrm{e}$ $\mathrm{CO}_{2}$ gerada pelo acúmulo de oxigênio, liberado pela fotossíntese, ao redor de células isoladas, favoreceu a atividade fotorrespiratoria. O amônio formado, provavelmente, inibe a atividade da enzima permease para o nitrato, evitando o seu consumo, o que não ocorre com o nitrito. As medidas da liberação de oxigênio dependente da luz e da atividade das enzimas assimilatórias de 
nitrogênio, incluindo a redutase do nitrito (RNi) e a glutamina sintetase (GS), determinadas sob condições que estimulam a fotorrespiração, dão suporte a esta hipótese.

A reassimilação do amônio liberado durante o processo fotorrespiratorio em plantas $\mathrm{C}_{3}$ representa cerca de $90 \%$ do fluxo por meio da rota GS/GOGAT nas folhas (Stitt et al., 2002). A menor atividade da enzima RN em plantas jovens de café cultivadas a pleno sol e, conseqüentemente, o acúmulo de nitrato, poderiam estar relacionados com o aumento da assimilação do amônio proveniente da fotorrespiração por meio das atividades das enzimas GS ou GOGAT.

São escassas as informações sobre a atividade da glutamina sintetase (GS) em mudas de café, bem como não foi devidamente explicada as razões do comportamento diferencial da redutase do nitrato (RN) em cafeeiro em relação à maioria das plantas. Estas observações justificam a realização de pesquisa exploratória sobre o assunto, com a finalidade de ampliar os conhecimentos nessa área da ciência agronômica.

Esta pesquisa foi realizada com o objetivo de avaliar as atividades enzimáticas da redutase do nitrato (RN) e da glutamina sintetase (GS) em mudas de café cultivadas a pleno sol (100 \% de luz) e a meia sombra (50 \% de luz) em função dos atributos ecofisiológicos. 


\section{REVISÃO DE LITERATURA}

\subsection{Classificação taxonômica do cafeeiro}

O café pertence à família Rubiaceae a qual abrange mais de 10.000 espécies agrupadas em 630 gêneros. As espécies do gênero Coffea distribuemse, geograficamente, em uma ampla região do continente Africano, em Madagascar e regiões vizinhas (Berthaud \& Charrier, 1988).

Pela classificação mais recente, segundo Bridson \& Verdcourt (1988) e Bridson (1994), os cafeeiros são agrupados em dois gêneros: Psilanthus Hook. e Coffea L. os quais se diferenciam por particularidades nas estruturas florais.

Entre as formas selvagens de cafeeiro algumas apresentam características vantajosas do ponto de vista da resistência a moléstias e a pragas, tolerância à seca e a outras variações do ambiente.

Embora exista um grande número de espécies de café somente a Coffea arabica L. e a Coffea canephora Pierre têm importância econômica, uma vez que, aproximadamente, $70 \%$ do café comercializado provêm das cultivares de arábica e $30 \%$ das cultivares de canéfora (Berthaud \& Charrier, 1988).

\subsection{Aspectos ecofisiológicos do cafeeiro arábica}

A espécie Coffea arabica L. é nativa de uma região restrita e marginal às demais espécies de café, localizada no Sudoeste da Etiópia, Sudeste do Sudão e ao Norte do Quênia, entre 1.000 a 3.000 m de altitude (Carvalho, 1946).

As cultivares de C. arabica L., na grande maioria, são derivadas das variedades Típica, introduzida no Brasil em 1727, e Bourbon, oriunda da ilha de mesmo nome (Anthony et al., 2001). Embora a base genética dessa espécie 
seja pequena (Berthaud e Charrier, 1988), as cultivares comercializadas possuem grande variabilidade devido a uma série de mutações e de cruzamentos naturais (Krug et al., 1939). Este fato justifica as possíveis alterações fisiológicas entre as primeiras plantas de café e àquelas cultivadas atualmente.

No ambiente de origem da espécie Coffea arabica $L$. as plantas vivem em sub-bosque, encontradas em altitudes variáveis entre 1.600 a $2.800 \mathrm{~m} \mathrm{e}$ com pouca oscilação da temperatura atmosférica. Nestas condições, a temperatura, praticamente, não ultrapassa $30^{\circ} \mathrm{C}$ e, raramente, atinge valores inferiores a $5^{\circ} \mathrm{C}$, com médias anuais ao redor de $20^{\circ} \mathrm{C}$. As chuvas são bem distribuídas e oscilam entre 1.600 a $2.000 \mathrm{~mm}$ por ano, sendo o período seco inferior a três meses (Sylvain, 1955; Carr, 2001). De acordo com Cannel (1985) as respostas fisiológicas dessas plantas podem ser compreendidas com base no conhecimento das condições de sua origem, admitindo que a fotossíntese do cafeeiro seja típica de plantas adaptadas à sombra.

A regulação estomática é um mecanismo utilizado para evitar a perda de água pelas plantas, a qual é afetada pelo deficite de pressão de vapor na espécie Coffea arabica L., conforme verificaram Hernandes et al. (1989), na pesquisa realizada sobre a condutância foliar à difusão de gases em função da umidade atmosférica.

Maestri \& Gomes (1961) estudando a exposição das mudas de café em condições de viveiro a $25 \%, 50 \%, 75 \%$ e $100 \%$ de luz, concluíram que a matéria seca total, a área foliar e o número médio de folhas aumentaram com a diminuição da luz até $50 \%$.

\subsection{Assimilação de nitrogênio pelas plantas}

A assimilação redutiva do nitrogênio é um processo dispendioso energeticamente às plantas, razão porque ocorre, predominantemente, nas folhas, centro da síntese de energia (ATP) e agentes redutores (fornecedores de elétrons). $\mathrm{O}$ processo de incorporação do $\mathrm{N}$ compete com a fotossíntese por 
massa (carboidrato) e energia, consumindo 12 ATPs para cada $\mathrm{N}$ assimilado pela planta (Bloom et al., 1992).

O excesso de amônio no cloroplasto é prejudicial aos vegetais, pois compromete o fluxo de elétrons pela redução do gradiente de $\mathrm{pH}$ entre $\mathrm{o}$ estroma ( $\mathrm{pH}$ elevado, presença de $\left.\mathrm{OH}^{-}\right)$e o lume $\left(\mathrm{pH}\right.$ baixo, presença de $\mathrm{H}^{+}$) (Bloom, 1997). O amônio $\left(\mathrm{NH}_{4}{ }^{+}\right)$no estroma reage com a hidroxila $\left(\mathrm{OH}^{-}\right)$e forma amônia $\left(\mathrm{NH}_{3}\right)$ provocando o abaixamento do $\mathrm{pH}$, conforme apresentado na reação 1:

$\mathrm{NH}_{4}{ }^{+}$(estroma $)+\mathrm{OH}^{-}(\mathrm{pH}$, elevado $) \quad \Longrightarrow \mathrm{NH}_{3}$ (abaixa $\mathrm{pH}$ do estroma)

em que a amônia gerada no estroma (reação 1), depois de atravessar o tilacóide, reage com $\circ \mathrm{H}^{+}$presente no lume, formando amônio, conforme a reação 2:

$$
\mathrm{NH}_{3} \text { (lume) }+\mathrm{H}^{+}(\mathrm{pH} \text {, baixo }) \quad \Longrightarrow \quad \mathrm{NH}_{4}{ }^{+} \text {(eleva } \mathrm{pH} \text { do lume) }
$$

e, em consequência, como resultado líquido dessas reações ocorre a diminuição da concentração de $\mathrm{OH}^{-}$do estroma e de $\mathrm{H}^{+}$do lume e, assim, reduz-se o gradiente de pH (Bloom, 1997). Do exposto, haverá comprometimento do fluxo eletrônico o que acabará prejudicando a produção de carboidrato.

\subsection{Características da enzima redutase do nitrato - RN}

A redutase do nitrato (RN) catalisa o primeiro passo enzimático da assimilação de nitrogênio pelas plantas superiores por meio da redução do nitrato $\left(\mathrm{NO}_{3}{ }^{-}\right)$a nitrito $\left(\mathrm{NO}_{2}{ }^{-}\right)$(Oaks, 1994; Yaneva et al., 2000), conforme esquematizado na expressão 3 : 
$\mathrm{NO}_{3}^{-}+\mathrm{NADPH}+2 \mathrm{H}^{+}+2 \mathrm{e}^{-} \stackrel{\mathrm{RN}}{\longrightarrow} \mathrm{NO}_{2}^{-}+\mathrm{NADP}^{+}+\mathrm{H}_{2} \mathrm{O}$

Essa enzima (RN) é uma flavoproteína formada por duas subunidades idênticas, com três grupos - FAD, heme e um complexo constituído entre o molibdênio (Mo) e uma molécula orgânica a pterina (Mendel \& Stallmeyer, 1995; Campbell, 1999), razão porque é, também, denominada uma molibdopterina.

A seqüência de aminoácidos da $\mathbf{R N}$ polipeptídica foi identificada mediante a clonagem dessa enzima. Existem, atualmente, mais de 40 seqüências da RN que constitui as formas da enzima das plantas superiores, algas e fungos. Comparando as seqüências da RN com aquelas das proteínas e enzimas conhecidas, verifica-se que a RN possui, aproximadamente, 917 resíduos de aminoácidos em cada subunidade, cada um deles contendo todos os cofatores, similares à proteína arabidopsis NIA2, tornando esta última um modelo representativo da RN (Campbell, 1999).

A maioria das formas da enzima $\mathbf{R N}$ das plantas utiliza o agente redutor NADH produzido no citossol e não o redutor NADPH formado no cloroplasto (Solomonson \& Barber, 1990). Entretanto, Crawford et al. (2000) afirmam que algumas formas dessa enzima (RN), com dupla especificidade, podem utilizar tanto o redutor NADPH quanto NADH.

A enzima RN está localizada, primariamente, no citossol das células corticais da epiderme da raiz e nas células mesofílicas da parte aérea (Rufty et al., 1986; Vaughn \& Campbell, 1988).

\subsection{Regulação da atividade da redutase do nitrato (RN)}

Segundo Galangau et al. (1988) e Vincentz et al. (1993) a atividade da enzima RN nas folhas e raízes pode ser induzida pela presença do substrato $\left(\mathrm{NO}_{3}{ }^{-}\right)$. Havendo nitrato ocorre um estímulo à síntese de novo da referida 
enzima (Hewitt et al., 1976), enquanto que deficite hídrico moderado, da ordem de $-0,8 \mathrm{MPa}$ a $-2,0 \mathrm{MPa}$, pode reduzir sua produção em $20 \%$, chegando a $50 \%$ quando a planta sofre um estresse intenso (Hsiao, 1979). Segundo Crocomo (1985) a menor atividade da redutase do nitrato em plantas sob estresse hídrico se deve ao decréscimo no fluxo do substrato $\left(\mathrm{NO}_{3}{ }^{-}\right)$por falta de umidade, principal fator regulador da síntese dessa enzima.

O fluxo catalítico da $\mathbf{R N}$ ou a capacidade total de redução do nitrato pelas plantas depende: (i) da disponibilidade de substrato no citoplasma (concentração em estado de equilíbrio do NADPH e nitrato); (ii) do nível de RN funcional - quantidade de RN polipeptídica e da disponibilidade de cofatores e íons metálicos, FAD, heme, Fe, Mo-MPT (molibdênio-molibdopterina) e molibdênio; (iii) da intensidade da atividade da RN funcional (Campbell, 1999). Cada processo é regulado direta ou indiretamente e a capacidade de redução do nitrato é controlada em relação ao nível metabólico total da planta, por sensores e rotas de tradução de sinais.

A quantidade da glutamina livre e a sua proporção em relação ao glutamato disponível, assim como os teores de nitrato são, provavelmente, os metabólitos chaves que governam a capacidade de redução do nitrato na planta (Solomonson \& Barber, 1990; Crawford, 1995; Scheible et al., 1997). Em condições de baixo teor de glutamina e disponibilidade de nitrato, a intensidade da $\mathbf{R N}$ e a capacidade de redução do nitrogênio aumentam, enquanto que quantidades elevadas da glutamina diminuem a redução do nitrato e decresce a atividade da RN (feedback).

O teor de equilíbrio da RN é determinado pela taxa de sua degradação, assim como, pela taxa de síntese da mesma. A meia vida de uma proteína $\mathbf{R N}$, recém sintetizada, é de poucas horas na célula e quando a quantidade de nitrato diminui o teor da RN é rapidamente reduzido (Taiz \& Zeiger, 1998). Portanto, a planta não deve sofre estresse hídrico nos trabalhos que avaliam a atividade dessa enzima, exceto quando a falta de água é uma das variáveis experimentais, pois afetaria os resultados da pesquisa. 
A resposta das plantas à quantidade de nitrato depende de outros fatores, entre os quais o material genético e o ambiente como, por exemplo, a luz, os quais influenciam a RN, bem como outros componentes do metabolismo do nitrato (Campbell, 1999).

Em plantas sob condições ótimas de crescimento, a capacidade de redução do nitrato é, aproximadamente, o dobro das necessidades da planta. A atividade da RN varia durante o dia, apresentando baixa atividade no escuro (Stitt, 1987; Scheible et al., 1997). Para Kaiser \& Huber (2001) em condições normais de ativação e na presença de luz a sua ação seria da ordem de 70 \% a $90 \%$, reduzindo para $10 \%$ a $30 \%$ no escuro. Estes autores afirmam que a luz não é um sinal direto para a atividade dessa enzima (RN), pois mesmo sob intensa e contínua luminosidade a $\mathbf{R N}$ é inativa quando falta $\mathrm{CO}_{2}$, indicando que a fotossíntese é requerida para a sua ativação (RN).

Considerando a necessidade desse gás para a ação da enzima podese admitir, por hipótese, que as causas que afetam a entrada do $\mathrm{CO}_{2}$, como a abertura estomática, variável com a capacidade da planta de manter a turgidez, afetaria a eficiência da RN. O cafeeiro arábica, em razão das condições climáticas relativas à sua origem, pode apresentar menor atividade enzimática (RN) no período luminoso, devido à baixa condutividade hidráulica dessa espécie, característica de plantas de sub-bosque que se desenvolvem sob elevada umidade relativa do ar.

Com base em experimentos efetuados com espinafre, excluindo o $\mathrm{CO}_{2}$ da atmosfera circundante às folhas, verificou-se decréscimo da atividade da RN (Kaiser \& Brendle-Behnisch, 1991). Esta constatação indica que a redução do nitrato é sensível à resistência estomática, de maneira que em plantas com estômatos fechados, como acontece sob deficiência hídrica, para impedir a perda de água, prejudica a taxa fotossintética e a atividade da RN (Kaiser \& Huber, 2001). Provavelmente, os fotoassimilados exportados para fora do cloroplasto funcionam como sinalizadores capazes de ativar a RN. 
Roth et al (1996) examinando um mutante de milho deficiente em ribulose bifosfato carboxilase, que perdeu a capacidade de processar o ciclo de Calvin, obtiveram menor atividade da RN na presença de luz e também no escuro, dando suporte à hipótese de que a ativação da $\mathbf{R N}$ na presença de luz depende dos produtos desse ciclo. Entretanto, não está devidamente esclarecido quais são os componentes que estão envolvidos quando um sinal é transferido dos cloroplastos, onde a fotossíntese está ocorrendo, para dentro do citosol, local de ação da RN. Intermediários ou derivados do ciclo de Calvin como, por exemplo, açúcares ou açúcar fosfatado, são elos importantes (Huber et al., 1996; Provan \& Lillo, 1999). De acordo com Bachmann et al. (1995) a RN pode ser ativada no escuro por meio do fornecimento de açúcar às folhas. Além disso, a inativação dessa enzima (RN) no escuro foi atenuada em um mutante de Nicotiana sylvestris que não produz amido e acumula altos níveis de açúcar fosfato.

\subsection{Redutase do nitrato e luminosidade em café}

Estudando a assimilação do nitrogênio em mudas de café cultivadas sob diferentes exposições à luz e formas de nitrogênio (nitrato e amônia), Miranda Neto (1970) verificaram em plantas desenvolvidas com 68 \% e $48 \%$ de luz uma redução na transformação do nitrato em nitrito nas plantas adubadas com nitrato. $\mathrm{O}$ fornecimento de amônia como fonte de nitrogênio, sem inibidor do processo de nitrificação, proporcionou uma maior atividade da enzima (RN) nas plantas a pleno sol.

De acordo com Carvalho (1975) a deficiência de nitrogênio em mudas formadas a pleno sol sugere a existência de uma associação direta entre o uso de nitrogênio e a formação da enzima - RN. Trabalhando com duas fontes de nitrogênio (amoniacal e nítrica) sob duas condições de luminosidade (meia sombra e pleno sol), o autor concluiu que sob $50 \%$ de luz as plantas de café apresentaram os maiores valores para a altura de planta, área foliar, número de folhas, matéria seca total e atividade da redutase do nitrato. 
No trabalho realizado por Faleiros et al. (1975) que estudaram o efeito da adubação nitrogenada e o desenvolvimento das mudas de café sob $50 \%$ de luz e a pleno sol, os autores constataram que nas plantas sombreadas parcialmente ( $50 \%$ de luz) a atividade da redutase do nitrato foi mais elevada.

Cordeiro et al. (1984) estudaram a atividade da redutase do nitrato em plantas jovens de cacau e de café (Coffea arabica L.) na luz e no escuro. Os autores verificaram que essas plantas apresentaram maior atividade da redutase do nitrato em ambiente escuro, comparativamente aos resultados obtidos nas plantas iluminadas. Resultado semelhante foi encontrado por Carelli (1987) que constatou decréscimo na atividade da redutase (RN) durante as horas de luz e aumento no período de escuro.

Trabalhando com plantas jovens de café submetidas a diferentes quantidades de luz e de nitrogênio Carelli et al. (1990) observaram que as plantas cultivadas a pleno sol apresentaram menor atividade da redutase do nitrato em relação às plantas sombreadas, embora possuíssem teores elevados de açúcares totais (fonte de energia) e de nitrato (substrato).

A redutase do nitrato na parte aérea e nas raízes de mudas de cafeeiro, em função do período luminoso, associada aos teores de nitrato e carboidratos nesses órgãos, apresentou declínio gradual da atividade nas folhas no decorrer do período, seguido por um aumento da atividade nas primeiras horas de escuro, com pico no final da noite (Queiroz et al. 1993).

Fahl et al. (1994) estudaram os efeitos da quantidade de radiação luminosa (30 \%, $50 \%$ e $100 \%$ ) nos processos fisiológicos envolvidos com o crescimento vegetativo como a área foliar e a altura de planta, o teor de clorofila, nitrogênio total e a atividade da redutase do nitrato nas folhas de várias cultivares de café. Os autores verificaram, 150 dias após o início do experimento, diferentes respostas às quantidades de luz. A cultivar Apoatã C3597 da espécie Coffea canephora Pierre apresentou maior desenvolvimento quando cultivada a meia sombra ( $50 \%$ de luz) ao passo que as cultivares da espécie Coffea arabica L. como, por exemplo, Catuaí H 2077-2-5-81 e Mundo 
Novo LCP 388-17 não diferiram em relação ao crescimento quando expostas a $50 \%$ e $100 \%$ de luz. O sombreamento excessivo (30\% luz) reduziu o desenvolvimento das cultivares de Coffea arabica sem afetar a cultivar da espécie Coffea canephora. A massa foliar específica diminuiu com o aumento do sombreamento em todas as cultivares. Os teores de clorofila aumentaram com o sombreamento enquanto os teores de nitrogênio total decresceram. A atividade da enzima redutase do nitrato nas folhas aumentou com o nível de sombreamento das plantas em todas as cultivares.

\subsection{Características da glutamina sintetase - GS}

A principal rota de assimilação do nitrogênio amoniacal $\left(\mathrm{NH}_{4}{ }^{+}\right)$nas plantas se da por meio da atividade da enzima glutamina sintetase (GS), a qual ocorre em diferentes isoformas e localizações na planta (Miflin et al., 1981; McNally et al., 1983; Hirel et al., 1984).

A enzima GS catalisa a conversão do aminoácido glutamato (GLU) em glutamina (GLN) por meio da reação que envolve a participação de GLU, amônio, ATP e um cátion divalente como cofator, conforme apresentada na expressão 4.

$$
\text { Glutamato }(\mathrm{GLU})+\mathrm{NH}_{4}^{+}+\mathrm{ATP} \underset{\left(\mathrm{Mg}^{2+}, \mathrm{Mn}^{2+}, \mathrm{Co}^{2+}\right)}{\longrightarrow \text { GS }} \text { glutamina }(\mathrm{GLN})+\mathrm{ADP}+\varepsilon
$$

Quando o cofator é o íon $\mathrm{Mg}^{+2}$ o $\mathrm{Km}$ para o amônio está entre 10 e 50 $\mu \mathrm{M}$ (Miflin et al., 1981). Uma vez formada a GLN pode ser utilizada em diversos eventos metabólicos, cedendo o nitrogênio assimilado para a formação de outros compostos nitrogenados, sendo, juntamente com a asparagina e ureídeos, os principais compostos nitrogenados translocados nas plantas (Joy, 1988). 
Estruturalmente a enzima GS é composta, predominantemente, de oito subunidades, resultando num arranjamento octamérico. Cada subunidade tem massa molecular em torno de $47 \mathrm{kDa}$ que resulta numa massa molecular total da enzima igual a 380 kDa (Cullimore et al., 1983; Robert \& Wong, 1986; Cai \& Wong, 1989).

McNally \& Hirel (1983) sugeriram que havia duas isoformas da enzima GS nas plantas, uma localizada no citoplasma $\left(G_{1}\right)$ e a outra no cloroplasto ou plastídio $\left(\mathrm{GS}_{2}\right)$.

A partir de cloroplastos de tabaco, utilizando dodecil sulfato de sódio em gel de poliacrilamida em HPLC, foi purificada e identificada uma enzima $\mathrm{GS}_{2}$ (Hirel et al., 1984). Os autores observaram a ocorrência de uma subunidade polipeptídica com peso molecular de $45 \mathrm{kDa}$. Com base nesse resultado foi sugerida uma composição protéica de 4 subunidades diferentes, com eventuais modificações pós-transducionais e ou pós-transcricionais.

Ericson (1985) purificou a $\mathrm{GS}_{2}$ a partir de cloroplastos de espinafre identificando uma proteína com peso molecular de $360 \mathrm{kDa}$, composta por oito subunidades de $44 \mathrm{kDa}$.

Em estudo realizado sobre a ocorrência de isoenzimas da glutamina sintetase (GS) em Chrolela kessleri foi observada a mesma massa molecular para $\mathrm{GS}_{1}$ e $\mathrm{GS}_{2}$ em torno de $350 \mathrm{kDa}$, com predominância da $\mathrm{GS}_{1}$ da ordem de $60 \%$ a $80 \%$ em relação a $\mathrm{GS}_{2}$, bem como uma maior estabilidade da $\mathrm{GS}_{1}$ ao calor $-30^{\circ} \mathrm{C}$ durante 30 minutos (Sumar et al., 1984).

Segundo Bennett \& Cullimore (1989) e Cock et al. (1991) no feijoeiro (Phaseolus vulgaris L.) existe, pelo menos quatro isoformas da enzima GS, inclusive em radículas de plântulas em germinação, assim como isoformas específicas para as plantas noduladas.

Nas folhas também existem duas enzimas diferentes a $\mathrm{GS}_{1}$ e a $\mathrm{GS}_{2}$. A $\mathrm{GS}_{1}$ é restrita ao citossol enquanto a $\mathrm{GS}_{2}$ ao cloroplasto (Hirel et al., 1984). Tem sido sugerido que a enzima $\mathrm{GS}_{1}$ possui a função de assimilação da amônia no citossol em condições de escuro (McNally et al., 1983). Segundo Edwards \& 
Coruzzi (1989) a enzima $\mathrm{GS}_{2}$ das folhas é induzida pela luz e o íon $\mathrm{NH}_{4}{ }^{+}$, estando envolvida, também, no uso do $\mathrm{NH}_{4}{ }^{+}$da fotorrespiração. Wallsgrove et al. (1987) demonstraram que a amônia produzida durante a fotorrespiração pode ser reassimilada pela planta no cloroplasto.

De acordo com Lam et al. (1996) a enzima GS, localizada nos plastídios das raízes, forma $\mathrm{N}$-amida consumido in loco, enquanto a GS dos cloroplastos foliares reassimila o nitrogênio na forma amoniacal $\left(\mathrm{NH}_{4}{ }^{+}\right)$formado durante a fotorrespiração. A quantidade de carboidrato e de radiação influencia a expressão das formas dessa enzima presente nos plastídios, sem efeito sobre as formas citosólicas.

De maneira semelhante à $\mathbf{R N}$ a regulação da atividade da glutamina sintetase (GS) pode ser induzida por diferentes estímulos externos ou fisiológicos, dependendo do órgão da planta ou da isoforma da GS (PujadeRenaud et al., 1994). A luz, por exemplo, aumenta a quantidade de RNAm da enzima $\mathrm{GS}_{2}$ em folhas de ervilha, fumo e tomate (Becker et al., 1992). Edwards \& Coruzzi (1989) observaram que a expressão de um gene nuclear para $\mathrm{GS}_{2}$ é afetada, sensivelmente, pela luminosidade. Tjaden et al. (1995) descreveram a flutuação da atividade da enzima $\mathrm{GS}_{2}$ conforme a quantidade de radiação e da atividade da $\mathrm{RN}$, observando aumentos da GS na presença de luz concomitantemente ao aumento da atividade da RN.

Além da atividade da sintetase na assimilação do amônio em compostos orgânicos a GS atua biossintéticamente na produção de $\gamma$ - glutamil hidroxamato a partir do glutamato, ATP e hidroxalamina (Franden \& Robertson, 1980).

A partir da análise de extratos Woolfolk \& Stadtman (1964), concluíram que a atividade da GS poderia ser quantificada por meio da formação do $\gamma$ glutamil hidroxamato, a qual pode ser inibida pela ação do AMP, GTP, CTP, alanina, glicina e triptofano nas concentrações de 0,002 a 0,005 M.

Análises eletroforéticas evidenciaram que a enzima GS é composta por dois tipos de subunidades polipeptídicas. Tanto a isoforma da GS presente nas 
raízes como nas folhas são compostas de polipeptídeos denominados $\alpha$ e $\beta$ (Lara et al., 1984). Nos nódulos, as subunidades que formam a enzima são do tipo $\beta$ e $\alpha$, as quais diferem entre si no ponto isoelétrico, mas não em relação ao tamanho. Assim, a $\mathrm{GS}_{\mathrm{n} 2}$ seria composta de um conjunto formado apenas por subunidades $\beta$, caracterizada como uma enzima homo-octamérica. 


\section{MATERIAL E MÉTODOS}

\subsection{Localização do experimento}

O experimento foi instalado em vasos na casa de vegetação do Laboratório de Biotecnologia Agrícola do Departamento de Ciências Biológicas da Escola Superior de Agricultura "Luiz de Queiroz", Universidade de São Paulo, Piracicaba, SP.

De acordo com a classificação de Köppen o clima regional é do tipo Cwa, tropical de altitude com inverno seco. As coordenadas geográficas da região são: $22^{\circ} 42^{\prime} 30^{\prime \prime}$ de latitude sul, $47^{\circ} 38^{\prime} 00^{\prime \prime}$ de longitude oeste e altitude de $550 \mathrm{~m}$.

\subsection{Formação das mudas de café}

Para a formação das mudas de café foram utilizadas sementes da cultivar Obatã IAC 1669-20 da espécie Coffea arabica L., cujas características principais são: porte baixo, tolerância ao agente da ferrugem, elevada capacidade produtiva e adaptabilidade para o plantio adensado ou em renque.

As sementes foram distribuídas em germinadores de areia na proporção de $1 \mathrm{~kg} \mathrm{~m}^{-2} \mathrm{e}$, posteriormente, as plântulas germinadas foram repicadas em tubetes no estádio de folhas cotiledonares expandidas - "orelha de onça", conforme recomendações do IBC (1986).

Para o transplante foi retirado o terço final da raiz principal para evitar o desvio lateral das mesmas. Na seqüência, a muda foi colocada em orifícios abertos no substrato e, em seguida, efetuou-se uma leve compressão 
para eliminar os espaços com ar próximo das raízes, com a finalidade de favorecer a sobrevivência e a fixação da planta.

Após o transplante as mudas permaneceram trinta dias no "viveiro berçário" com 50 \% de luz, proporcionada pela cobertura da tela sombrite. As plantas nesse período foram irrigadas com turno de $2 \mathrm{~h}$ durante cinco minutos, das 8:00 h às 18:00 h, perfazendo cinco irrigações diárias.

Quando as mudas apresentavam seis pares de folhas expandidas as mesmas foram transferidas para vasos contendo $5 \mathrm{~L}$ de uma mistura de terra (70 \% volume) e esterco (30\% volume), à qual foi adicionada $5 \mathrm{~kg}$ de superfosfato simples, $0,5 \mathrm{~kg}$ de cloreto de potássio e $2,5 \mathrm{~kg}$ de calcário dolomítico por metro cúbico (Thomaziello et al., 1996). Ao volume de 1000 litros formado pela mistura de terra $(70 \%)$ e esterco (30 \%) foi adicionada as respectivas quantidades de fertilizantes e corretivos.

Após o plantio das mudas nos vasos, as mesmas permaneceram durante 45 dias em ambiente com $50 \%$ de luz, sob tela sombrite, visando à aclimatação e sobrevivência das plantas. No final do período foram selecionadas 40 plantas uniformes quanto ao porte e vigor e que já haviam emitido o sétimo par de folhas, uma garantia de que as mesmas haviam sobrevivido ao estresse provocado no plantio.

\subsection{Tratamentos utilizados e condução das plantas}

As plantas selecionadas foram deixadas a pleno sol até a emissão do oitavo par de folhas, aproximadamente, 30 dias após o período de aclimatação. Posteriormente, 20 plantas continuaram expostas ao sol (T1: $100 \%$ de luz) e 20 plantas foram submetidas à meia sombra (T2: $50 \%$ de luz), utilizando tela sombrite. As plantas dos tratamentos a pleno sol e a meia sombra permaneceram três meses nestas condições.

Durante o experimento as plantas foram, periodicamente, irrigadas com a finalidade de mantê-las túrgidas - sem estresse hídrico. 
A adubação foi feita usando nitrogênio $(N)$ e potássio $(K)$ em duas coberturas, sendo a primeira realizada 20 dias após a emissão do nono par de folhas, fornecendo $25 \mathrm{mg}$ planta $^{-1}$ de $\mathrm{N}$ e K. Trinta dias depois da primeira cobertura, quando as plantas apresentavam o décimo par de folhas e ramos plagiotrópicos em crescimento, foi realizada a segunda cobertura, sendo aplicada $50 \mathrm{mg}$ planta $^{-1}$ de $\mathrm{N} \mathrm{e} \mathrm{K}$, usando como fonte de $\mathrm{N}$ a uréia $(45 \% \mathrm{~N})$ e de $\mathrm{K}$, o cloreto de potássio $\left(60 \% \mathrm{~K}_{2} \mathrm{O}\right)$.

O controle fitossanitário foi efetuado, preventivamente, por meio da aplicação no solo de dissulfoton associado ao triadimenol $\left(0,5 \mathrm{~g} \mathrm{planta}^{-1}\right.$ do produto comercial baysiston).

Esses cuidados tinham como objetivo evitar que as plantas fossem submetidas a estresses bióticos (pragas e ou doenças) e ou abióticos (falta de água), exceto em relação à variável em estudo - nível de exposição das plantas à luminosidade.

\subsection{Variáveis avaliadas}

Nas mudas de cafeeiro arábica com doze meses de idade, conduzidas em casa de vegetação a pleno sol (T1: 100 \% luz) e a meia sombra (T2: 50 \% de luz), foram efetuadas as determinações das atividades das enzimas redutase do nitrato - RN ( $\mu \mathrm{mol} \mathrm{NO}{ }_{2}^{-} h^{-1} \mathrm{~g}^{-1} \mathrm{MF}$ ) e da glutamina sintetase - GS ( $\mu \mathrm{M}$ de $\gamma-\mathrm{GH} \mathrm{h}^{-1} \mathrm{mg}^{-1}$ proteína).

Com a finalidade de fornecer subsídios à compreensão dos resultados foram feitas avaliações ecofisiológicas complementares como: (i) temperatura atmosférica, no ambiente em que as mudas foram conduzidas $-\mathrm{Ta}\left({ }^{\circ} \mathrm{C}\right.$ ), (ii) temperatura foliar - Tf $\left({ }^{\circ} \mathrm{C}\right)$, (iii) radiação fotossinteticamente ativa - PAR $(\mu \mathrm{mol}$ $\left.\mathrm{m}^{-2} \mathrm{~s}^{-1}\right)$, (iv) condutância estomática $-\mathbf{g s}\left(\mathrm{mol} \mathrm{m}^{-2} \mathrm{~s}^{-1}\right)$, (v) taxa de transpiração foliar - E (mmol m $\left.\mathrm{m}^{-2} \mathrm{~s}^{-1}\right)$, (vi) taxa de fotossíntese líquida - $\mathbf{A}\left(\mu \mathrm{mol} \mathrm{CO}_{2} \mathrm{~m}^{-2} \mathrm{~s}^{-1}\right)$ e (vii) teor de proteína total solúvel - PTS ( $\mathrm{mg} \mathrm{PTS}^{-1} \mathrm{MF}$ ). 
O crescimento vegetativo das plantas foi analisado mediante a determinação das variáveis: (viii) altura de plantas $-\mathbf{H}(\mathrm{cm}$ ), (ix) diâmetro de caule - DC (mm), (x) número de ramos plagiotrópicos - NRP, (xi) número de folhas - NF e (xii) matéria seca de folhas - MS (g).

\subsection{Preparo dos extratos para análise das atividades enzimáticas}

De cada planta (repetição) coletou-se $1,0 \mathrm{~g}$ de material vegetal na forma de discos de folhas (Figura 1), o qual foi fracionado e submetido a uma pequena quantidade de nitrogênio líquido durante a maceração, tendo sido adicionado 2,0 $\mathrm{ml}$ da solução de extração, antes desse processo (maceração em graal).

O material foi homogeneizado e depois centrifugado a $5000 \mathrm{rpm}$ durante 5 minutos a $4^{\circ} \mathrm{C}$. O material sobrenadante foi transferido para outro tudo de ensaio e acondicionado em recipiente com gelo moído e, em seguida, foi feita a determinação das atividades enzimáticas.

\subsubsection{Atividade da redutase do nitrato (RN)}

A determinação da atividade da redutase do nitrato foi feita empregando-se o ensaio in vivo modificado por Queiroz et al. (1991), com intervalo de $5 \mathrm{~h}$ entre as avaliações, efetuadas às 7:00 h, 12:00 h, 17:00 h e 22:00 h. Esse procedimento foi adotado para permitir a comparação da ação enzimática nas diferentes condições de luminosidade do experimento (pleno sol e 50 \% de luz) ao longo do período luminoso e a noite, em razão da variação da irradiância.

As amostras de tecido fresco foram coletadas e lavadas com água deionizada. Em seguida, retirou-se discos foliares de $100 \mathrm{mg}$ de massa e 0,5 $\mathrm{cm}$ de diâmetro (Figura 1), os quais foram colocados em tubos de ensaio contendo $5 \mathrm{ml}$ de solução tampão $\mathrm{PO}_{4}$, pH 7,4 $50 \mathrm{mM}+\mathrm{KNO}_{3} 200 \mathrm{mM}$.

Essas amostras foram infiltradas a vácuo durante 1 minuto com a finalidade de aumentar a penetração da solução nos tecidos. Posteriormente, 
os tubos de ensaio contendo o material vegetal foram incubados em banhomaria a $30^{\circ} \mathrm{C}$ por 1 hora ao abrigo da luz, envoltas com folha de alumínio. A paralização da reação foi feita com a adição de $1 \mathrm{ml}$ de sulfanilamida a $1 \% \mathrm{em}$ $\mathrm{HCl} 2 \mathrm{~N} \mathrm{e}$, a seguir, adicionou-se $1 \mathrm{ml} \mathrm{de} \alpha$-naftilenodiamino 0,05\%.

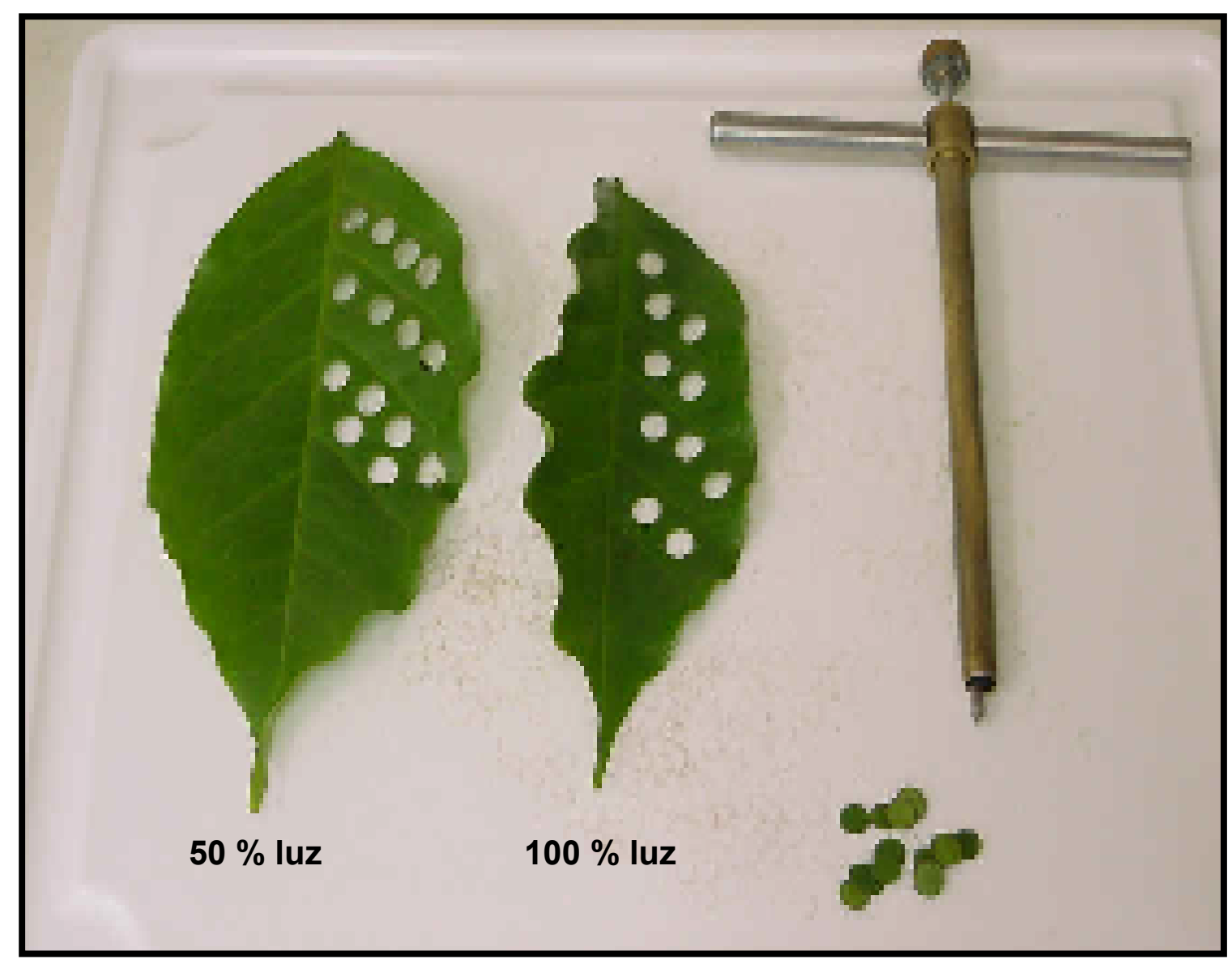

Figura 1 - Método de coleta de discos foliares para a determinação da atividade das enzimas redutase do nitrato e glutamina sintetase em folhas de Coffea arabica cv. Obatã IAC 1669-20 cultivadas a pleno sol e a meia sombra

A leitura foi feita em espectrofotômetro a $540 \mathrm{~nm}$, sendo a atividade da enzima determinada pela quantidade de nitrito $\left(\mathrm{NO}_{2}{ }^{-}\right)$produzida, comparando os 
valores obtidos com uma curva padrão para esse íon, previamente estabelecida. Os resultados obtidos dessa variável foram expressos em $\mu \mathrm{mol} \mathrm{NO}{ }_{2}^{-} \mathrm{h}^{-1} \mathrm{~g}^{-1} \mathrm{MF}$.

\subsubsection{Atividade da glutamina sintetase (GS)}

A atividade específica da sintetase da glutamina foi obtida utilizando o método proposto por Elliott (1953), o qual explora a atividade biossintética dessa enzima na formação de $\gamma$ - glutamil hidroxamato.

Essa reação foi realizada sob agitação contínua em banho-maria a $30^{\circ} \mathrm{C}$ em tubo de ensaio, no qual foram adicionados $0,25 \mathrm{ml}$ de tampão TRIS - HCL $200 \mathrm{mM}, \mathrm{pH}$ 7,5; 0,1 ml de ATP $50 \mathrm{mM}, \mathrm{pH}$ 7,0; 0,25 ml de glutamato de sódio $500 \mathrm{mM} ; 0,05 \mathrm{ml}$ de MgSO; 0,05 ml de cisteína $100 \mathrm{mM} ; 0,15 \mathrm{ml}$ de hidoxilamina $100 \mathrm{mM}, \mathrm{pH}$ 7,0 e 0,15 ml de extrato, totalizando 1 mililitro (ml).

Após o período de incubação a reação foi interrompida pela adição de 1 $\mathrm{ml}$ do reagente cloreto férrico $-\mathrm{FeCl}_{3}(10 \%) / \mathrm{TCA}(24 \%) / \mathrm{HCl}(6 \mathrm{~N}), 1: 1: 1$ formando um complexo marrom amarelado como precipitado. Em seguida, a mistura foi centrifugada a $5000 \mathrm{rpm}$ e no material sobrenadante foi realizada a leitura colorimétrica para determinar a formação de $\gamma$ - glutamil hidroxamato.

A leitura foi feita a $540 \mathrm{~nm}$ em espectrofotômetro marca HITACHI e modelo $U-3210$, sendo a determinação da atividade enzimática realizada a partir da comparação da leitura obtida com uma curva padrão, preparada previamente. Os resultados obtidos dessa variável foram expressos em $\mu$ moles $\gamma$-glutamil hidroxamato produzido por hora por miligrama de proteína ( $\mu \mathrm{M}$ de $\gamma-\mathrm{GH} \mathrm{h}^{-1} \mathrm{mg}^{-1}$ proteína).

\subsection{Avaliações ecofisiológicas}

As determinações das variáveis ecofisiológicas como a condutância estomática (gs, mol m $\mathrm{m}^{-2} \mathrm{~s}^{-1}$ ), taxa de transpiração $\left(\mathbf{E}, \mathrm{mmol} \mathrm{m}^{-2} \mathrm{~s}^{-1}\right)$, taxa de fotossíntese líquida (A, $\mu \mathrm{mol} \mathrm{CO}_{2} \mathrm{~m}^{-2} \mathrm{~s}^{-1}$ ), temperatura foliar (Tf, ${ }^{\circ} \mathrm{C}$ ), temperatura do $\operatorname{ar}\left(\mathrm{Ta},{ }^{\circ} \mathrm{C}\right)$ e radiação fotossinteticamente ativa (PAR, $\mu \mathrm{mol} \mathrm{m}{ }^{-2}$ $\mathrm{s}^{-1}$ ) foram efetuadas nas folhas utilizadas para a determinação da RN. A 
avaliação desses atributos ecofisiológicos foi feita utilizando um medidor portátil modelo LI - 6400 (LICOR NE, USA) (Figura 2), com intervalo de $5 \mathrm{~h}$ entre as avaliações, ou seja, às 7:00 h, 12:00 h e 17:00 h. Esse procedimento foi adotado para permitir a comparação da ação enzimática nas diferentes condições de luminosidade do experimento (T1: pleno sol e T2: meia sombra) ao longo do período luminoso, em função da variação diária da irradiância e dos referidos atributos ecofisiológicos (Ta, Tf, gs, E, A e PAR).

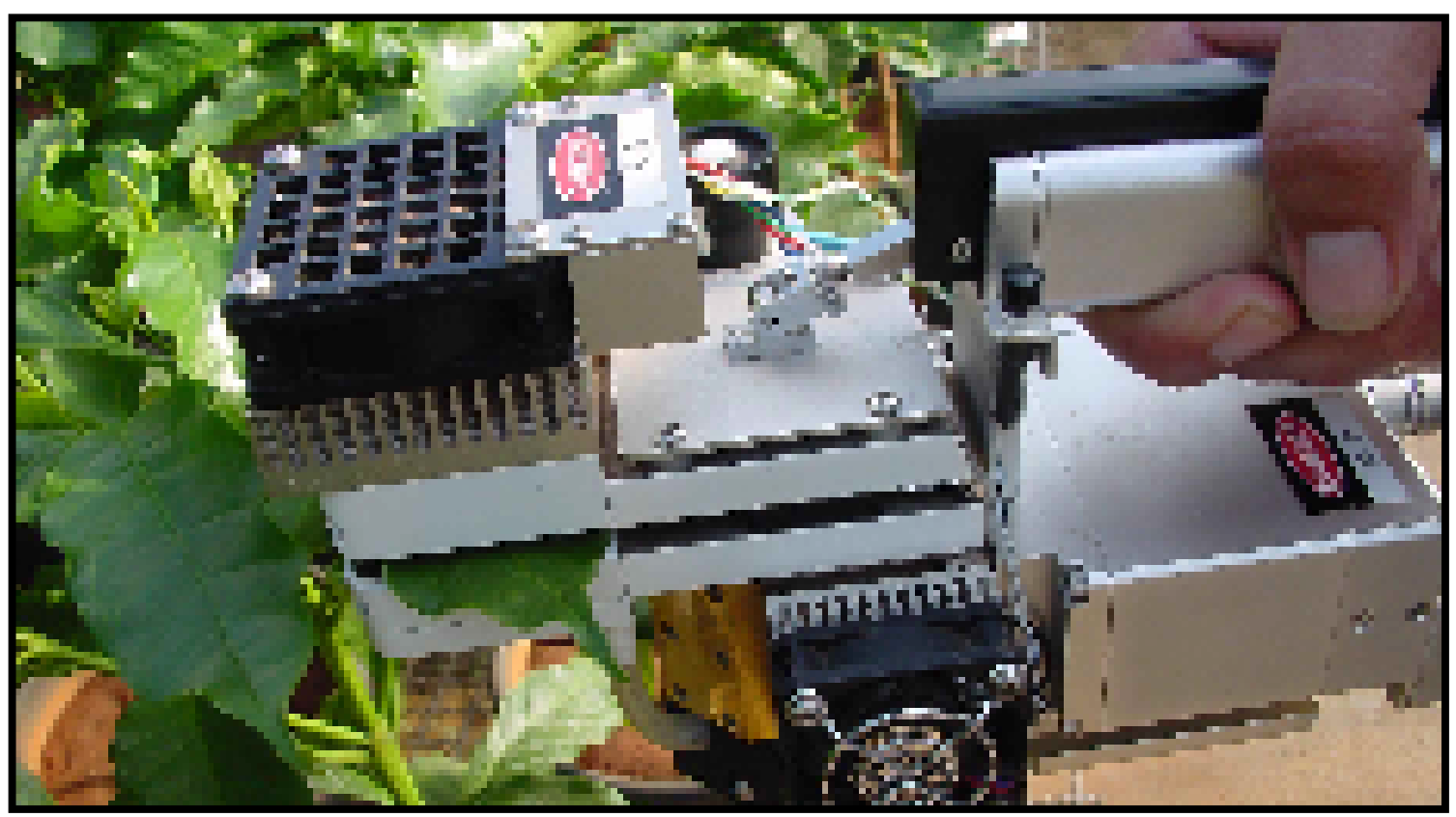

Figura 2 - Medidor portátil modelo LI - 6400 utilizado para determinar os atributos ecofisiológicos como a temperatura atmosférica (Ta), temperatura foliar (Tf), condutância estomática (gs), taxa de transpiração $(\mathbf{E})$, taxa de fotossíntese líquida $(\mathbf{A})$ e radiação fotossinteticamente ativa (PAR)

\subsection{Determinação do teor de proteína total solúvel (PTS)}

Para a determinação do teor de proteína total solúvel (PTS) foi utilizada a metodologia de Bradford (1976), usando extratos preparados com o tampão TRIS. 
Numa alíquota de $100 \mu \mathrm{l}$ do extrato foi acrescentada $5 \mathrm{ml}$ do reagente de BRADFORD resultando em uma mistura colorida, em que foi feita a leitura a 595 nm em espectrofotômetro marca HITACHI, modelo U - 3210 .

$O$ reagente de BRADFORD foi preparado com $100 \mathrm{mg}$ de COMASSIE BRILLIANT BLUE G - 250 dissolvidos em $50 \mathrm{ml}$ de etanol $95 \%$ e $100 \mathrm{ml}$ de $\mathrm{H}_{3} \mathrm{PO}_{4} 85 \%$. O volume dessa mistura foi aferido para 1 litro e filtrado duas vezes utilizando filtro de papel qualitativo da marca REAGEN.

O teor de proteínas total solúvel (PTS) das amostras foi calculado a partir de uma curva padrão feita com albumina de soro bovino (BSA), sendo os resultados obtidos dessa variável expressos em $\mathrm{mg} \mathrm{g}^{-1}$ de matéria fresca (MF).

\subsection{Análise vegetativa}

\subsubsection{Altura de planta $(\mathrm{H})$}

A altura $(\mathrm{H} ; \mathrm{cm})$ das plantas foi efetuada com uma régua milimetrada entre o nível do solo, na região do colo da planta, e a inserção do último par de folhas expandidas.

\subsubsection{Diâmetro do caule (DC)}

Esse parâmetro (DC; $\mathrm{mm}$ ) foi determinado utilizando um paquímetro digital, obtendo as medidas na região do caule localizado abaixo da cicatriz de inserção das folhas cotiledonares.

\subsubsection{Número de ramos plagiotrópicos (NRP)}

No final do experimento foram contados os ramos produtivos (NRP) emitidos pelas plantas de cada tratamento.

\subsubsection{Número de folhas da planta (NF)}

As folhas do caule e dos ramos produtivos foram, também, recolhidas e quantificadas (NF). 


\subsubsection{Matéria seca de folhas (MS)}

A matéria seca (MS; g) foi obtida por meio da determinação da massa de folhas em balança de precisão, após a secagem da planta em estufa a $70^{\circ} \mathrm{C}$ com circulação de ar forçada durante 36 horas.

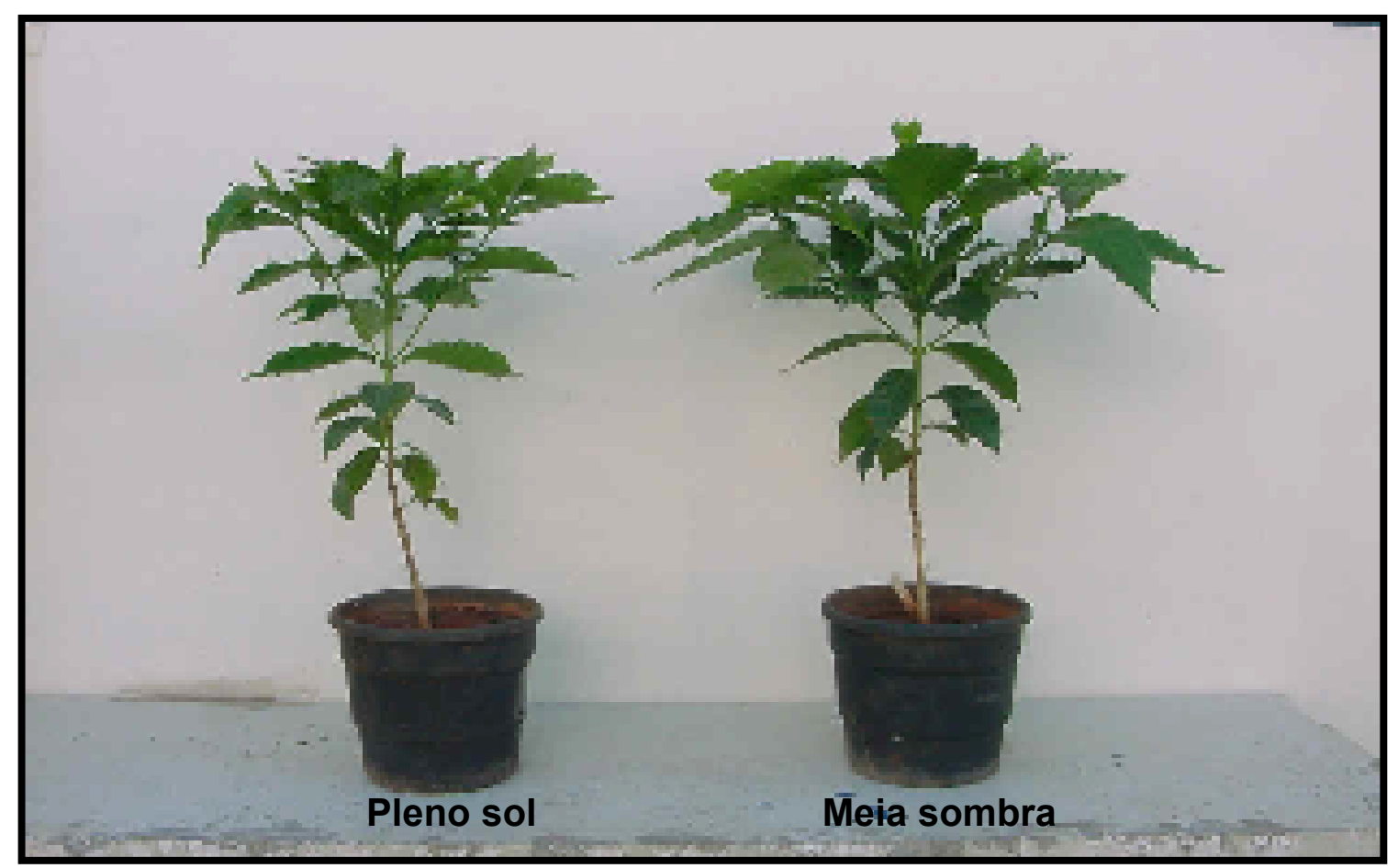

Figura 3 - Mudas de cafeeiro Coffea arabica L. cv Obatã IAC 1669-20, com doze meses de idade, cultivadas a pleno sol e a meia sombra

\subsection{Análise química de folhas}

\subsubsection{Preparo do material vegetal para análise}

A análise química para a determinação de macronutrientes e micronutrientes foi realizada no material vegetal proveniente das análises da redutase do nitrato (RN). As folhas e os discos foliares utilizados na determinação da atividade enzimática foram submetidos à secagem em estufa a $70^{\circ} \mathrm{C}$ com circulação de ar forçada durante 36 horas. Após o resfriamento do material realizou-se a medição da matéria seca (g), utilizando-se uma balança de precisão. 
Posteriormente, o material foi moído e preparado para a análise química, conforme metodologia proposta por Malavolta et al. (1989).

\subsubsection{Determinação de macro e micronutrientes}

Os teores de macronutrientes $(\mathrm{P}, \mathrm{K}, \mathrm{Ca}, \mathrm{Mg}$ e $\mathrm{S})$ e micronutrientes $(\mathrm{Cu}$, $\mathrm{Fe}, \mathrm{Mn}$ e $\mathrm{Zn}$ ) foram obtidos através da digestão nitro-perclórica. $\mathrm{O} N$ foi determinado por meio da digestão sulfúrica e o B por incineração (Malavolta et al., 1989).

Para a digestão nitro-perclórica foi feita inicialmente à pesagem de $0,5 \mathrm{~g}$ de matéria seca (MS) do material a ser analisado, passando em seguida para o tubo de digestão em bloco de 40 provas, com $6 \mathrm{ml}$ de solução de ácido nítrico mais perclórico na relação $(4+0,5)$, com temperatura inicial de $50^{\circ} \mathrm{C}$. Em seguida para $75^{\circ} \mathrm{C}$ e $100^{\circ} \mathrm{C}$ por mais 15 minutos, depois para $120^{\circ} \mathrm{C}$ por 30 minutos e $160^{\circ} \mathrm{C}$ até a eliminação total da matéria orgânica, passando depois para $180^{\circ} \mathrm{C}$ visando à homogeneização dos volumes das amostras e, finalmente, para $210^{\circ} \mathrm{C}$ até a saída de fumos brancos ou redução do volume final. Foi utilizada $50 \mathrm{ml}$ de $\mathrm{H}_{2} \mathrm{O}$ deionizada no tubo e homogeneizado até dissolver os minerais.

Para a determinação do $\mathrm{P}$ foi coletado $1 \mathrm{ml}$ do extrato final da digestão nitro-perclórica e transferido para tubo de ensaio de $15 \mathrm{ml}$, adicionando ao mesmo $6 \mathrm{ml}$ de uma solução vanado-molíbdica ${ }^{1}$. O valor final foi obtido por determinação colorimétrica.

Foram feitos, inicialmente, padrões de uma solução 1000 ppm de $\mathrm{P}$, com ácido (10 ml de solução nitro-perclórica 4+0,5), nas concentrações de 5, 10, 20, 40, 60, 80 e 100 ppm de P partindo da solução de 1000 ppm. Para a determinação da curva padrão coletou-se $1 \mathrm{ml}$ de cada padrão mais $6 \mathrm{ml}$ de solução vanado-molíbdica ${ }^{1}$. 
Solução vanado-molíbdica":

* foi usado $125 \mathrm{~g}$ de molibdato de amônio em becker contendo $800 \mathrm{ml}$ de $\mathrm{H}_{2} \mathrm{O}$ deionizada aquecida a $80^{\circ} \mathrm{C}$, agitando-o até a dissolução e, em seguida, deixou esfriando;

* transferiu-se 6,25 g de metavanato de amônio para becker contendo 200 $\mathrm{ml}$ de $\mathrm{H}_{2} \mathrm{O}$ deionizada aquecida a $80^{\circ} \mathrm{C}$, agitando-o até dissolução e, em seguida, deixou esfriando;

* juntou-se a essa solução $700 \mathrm{ml}$ de $\mathrm{NHO}_{3}$ concentrado e deixou esfriar;

* misturou-se as duas soluções, previamente resfriadas, em balão de 2 litros e completou o volume com água deionizada;

* finalmente, misturou-se $250 \mathrm{ml}$ desta solução a $275 \mathrm{ml}$ de água deionizada.

A determinação do enxofre $(S)$ foi feita através da transferência de $10 \mathrm{ml}$ de extrato para tubo de ensaio de $30 \mathrm{ml}$, adicionando-se a este $1 \mathrm{ml}$ de $\mathrm{HCl} 6 \mathrm{~N}$ com $20 \mathrm{ppm}$ de $\mathrm{S}$, mais $0,5 \mathrm{~g}$ de $\mathrm{BaCl}_{2}$. Foram preparados padrões de 5, 15, 25, 40 e 50 ppm mediante solução estoque de $S$ a 1000 ppm. Utilizou-se, também, o método colorimétrico.

Por meio do uso de $1 \mathrm{ml}$ de extrato misturado a $19 \mathrm{ml}$ de óxido de lantânio a $0,1 \%$ em tubo de ensaio de $30 \mathrm{ml}$, os elementos $\mathrm{K}$, Ca e $\mathrm{Mg}$ foram quantificados por espectrofotômetro de absorção atômica com lâmpadas de catodo oco.

Os elementos $\mathrm{Cu}, \mathrm{Fe}, \mathrm{Mn}$ e $\mathrm{Zn}$ foram quantificados diretamente mediante a leitura no extrato nitroperclórico, por espectrofotômetro de absorção atômica.

O nitrogênio foi determinado utilizando o processo de digestão sulfúrica, pesando inicialmente $0,1 \mathrm{~g}$ de MS a qual foi transferida para tubo de digestão, onde foi adicionada $5 \mathrm{ml}$ da mistura digestora ${ }^{2}$ contendo ácido sulfúrico com sais e catalizadores. A temperatura foi aumentada de 50 em $50^{\circ} \mathrm{C}$ por aproximadamente 30 minutos até atingir $350^{\circ} \mathrm{C}$. Para a destilação utilizou-se o volume de $\mathrm{NaOH} \pm 15 \mathrm{~N}$ suficiente para neutralizar o ácido e deixar o meio alcalino, liberando assim a $\mathrm{NH}_{3}$, a qual foi fixada em solução indicadora de ácido 
bórico. Em seguida, fez-se a titulação com $\mathrm{H}_{2} \mathrm{SO}_{4}$ até a formação de $\left(\mathrm{NH}_{4}\right)_{2} \mathrm{SO}_{4}$ na presença de indicador ácido/base.

Solução digestora ${ }^{2}$ :

* colocou-se 2 litros de $\mathrm{H}_{2} \mathrm{O}$ em becker plástico de 4 litros;

* adicionou-se $1 \mathrm{~g}$ de $\mathrm{Na}_{2} \mathrm{SeO}_{3}$ (selenito de sódio) e dissolveu;

* adicionou-se $45 \mathrm{~g}$ de $\mathrm{CuSO}_{4} .5 \mathrm{H}_{2} \mathrm{O}$ e dissolveu;

* adicionou-se $190 \mathrm{~g}$ de $\mathrm{Na}_{2} \mathrm{SO}_{4}$ anidro e dissolveu;

* adicionou-se 1 litro de $\mathrm{H}_{2} \mathrm{SO}_{4}$ contendo $5 \mathrm{~g}$ de ácido salićlico dissolvido;

* adicionou-se 1 litro de $\mathrm{H}_{2} \mathrm{SO}_{4}$ concentrado até completar 2 litros de $\mathrm{H}_{2} \mathrm{SO}_{4}$.

A determinação de boro (B) foi feita em água quente usando aquecimento em microonda, tendo sido usado $10 \mathrm{~cm}^{3}$ de solo misturado com $20 \mathrm{ml}$ da solução extratora de cloreto de bário, formada pela dissolução de $1,25 \mathrm{~g} \mathrm{~L}^{-1}$ do sal em $1 \mathrm{~L}$ de água deionizada de acordo com metodologia proposta por Abreu et al. (2001).

\subsection{Delineamento experimental}

O experimento foi realizado em delineamento inteiramente casualizado utilizando dois tratamentos: T1 - plantas a pleno sol (PS: 100\% de luz) e T2 plantas a meia sombra (MS: $50 \%$ de luz), com cinco repetições. Cada repetição era constituída por uma planta por vaso, perfazendo 20 plantas por tratamento, em razão das avaliações serem realizadas em conjuntos de cinco plantas em quatro horários diferentes.

Os resultados obtidos para cada variável estudada foram submetidos à análise de variância para a comparação de médias entre os referidos tratamentos (T1 e T2). 


\section{RESULTADOS E DISCUSSÃO}

\subsection{Atividade da redutase de nitrato (RN)}

A atividade da enzima redutase de nitrato (RN) determinada a pleno sol (PS) decresceu ao longo do período luminoso (Figura 4), corroborando resultados anteriores obtidos por Cordeiro et al. (1984), Alves et al. (1985) e Queiroz et al. (1993).

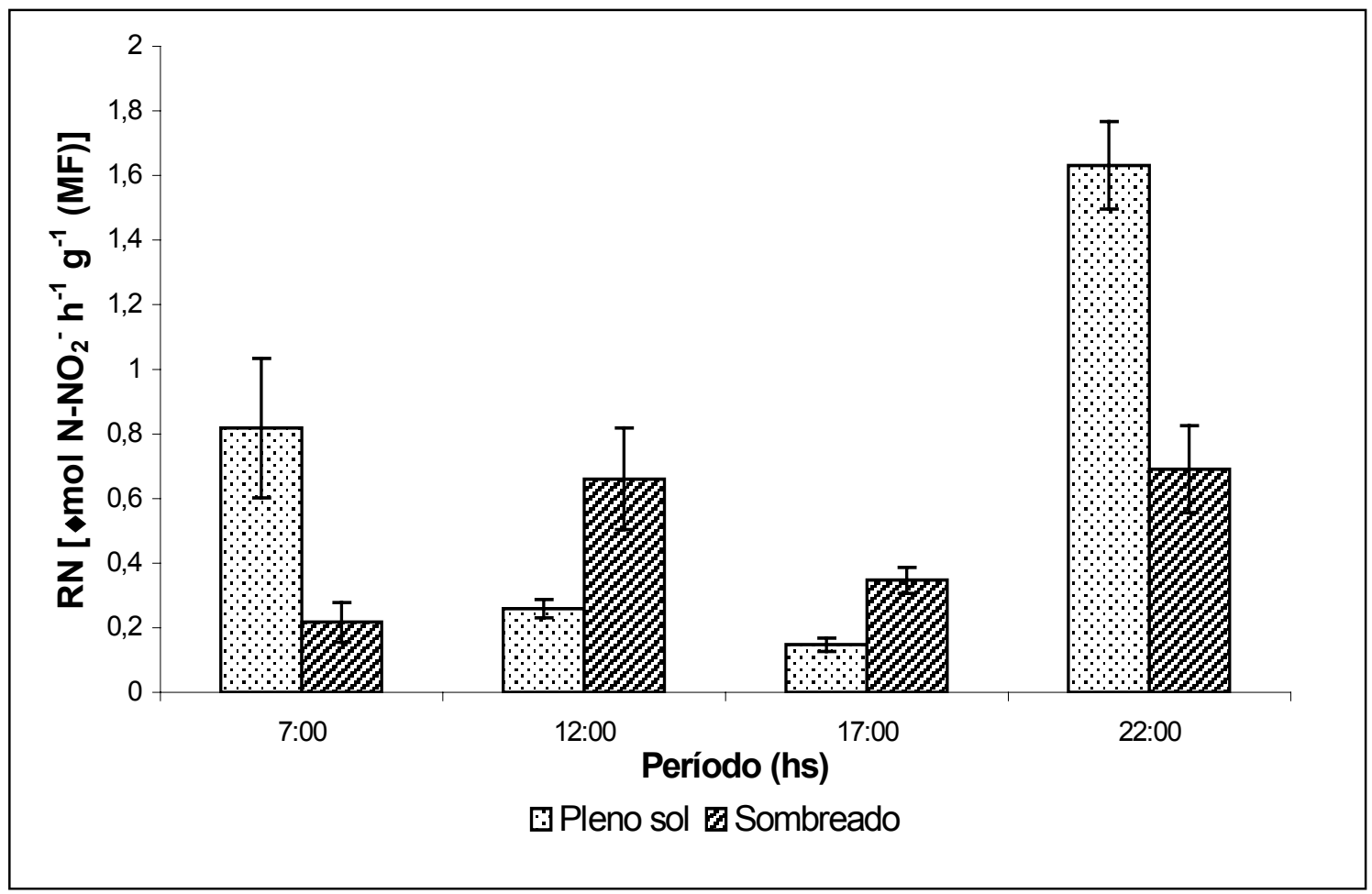

Figura 4 - Médias da atividade da redutase do nitrato (RN) em mudas de Coffea arabica L. cv Obatã IAC 1669-20 cultivadas a pleno sol e a meia sombra às 7:00 h, 12:00 h, 17:00 h e 22:00 h 
As médias obtidas para a atividade da $\mathbf{R N}$ às $7: 00 \mathrm{~h}$ nas plantas a pleno sol $\left(0,82 \mu \mathrm{mol} \mathrm{NO}{ }_{2}^{-} \mathrm{h}^{-1} \mathrm{~g}^{-1} \mathrm{MF}\right)$ foram $70 \%$ e $82 \%$ superiores àquelas determinadas às 12:00 $\mathrm{h}\left(0,26 \mu \mathrm{mol} \mathrm{NO}{ }_{2}^{-} \mathrm{h}^{-1} \mathrm{~g}^{-1} \mathrm{MF}\right)$ e às 17:00 $\mathrm{h}(0,15 \mu \mathrm{mol}$ $\mathrm{NO}_{2}^{-} \mathrm{h}^{-1} \mathrm{~g}^{-1}$ de MF), respectivamente (Figura 4). A atividade dessa enzima (RN) às 22:00 $\mathrm{h}$ mais que duplicou, uma vez que chegou a $1,63 \mu \mathrm{mol} \mathrm{NO}_{2}{ }^{-} \mathrm{h}^{-1} \mathrm{~g}^{-1}$ de MF em relação ao valor determinado às 7:00 $\mathrm{h}$.

Nas plantas a meia sombra (50 \% luz) a atividade da RN alternou ao longo do período luminoso $(7: 00 \mathrm{~h}$ às 17:00 h) apresentando uma tendência diferente do que foi observado em relação a atividade dessa enzima nas plantas expostas ao sol. Nas plantas conduzidas sob $50 \%$ de luz evidenciou uma atividade superior da $\mathbf{R N}$ durante o período luminoso, às 12:00 h $(0,66$ $\mu \mathrm{mol} \mathrm{NO}{ }_{2}^{-} \mathrm{h}^{-1} \mathrm{~g}^{-1}$ de MF).

Os resultados obtidos no presente experimento corroboram resultados publicados por vários autores, os quais verificaram que a atividade da enzima RN, nas folhas do cafeeiro, aumenta com o sombreamento, no período de maior irradiância (Miranda Neto, 1970; Carvalho, 1975; Faleiros et al., 1975; Fahl et al., 1994). Este comportamento pode ser explicado, em parte, pela reassimilação do nitrogênio liberado no processo fotorrespiratório cuja ocorrência pode ser inferida com base na elevada temperatura foliar $40,7^{\circ} \mathrm{C}$ em relação à temperatura do ar $38,8^{\circ} \mathrm{C}$ obtida nas plantas a pleno sol (Tabela 1). De acordo com Stitt et al. (2002) a assimilação do amônio liberado durante a fotorrespiração em plantas $\mathrm{C}_{3}$ representa cerca de $90 \%$ do fluxo por meio da rota GS/GOGAT. O aumento da atividade da $\mathbf{R N}$ às $12: 00 \mathrm{~h}$ a meia sombra pode ser, também, uma consequência da absorção de nitrogênio do solo, uma vez que a condutância estomática (Figura 8) e a taxa de transpiração (Figura 9) mantiveram o fluxo xilemático, tendo apresentado valores superiores àqueles obtidos nas plantas expostas ao sol. Esta afirmação é reforçada considerando o teor de $\mathrm{N}$ foliar determinado às $12: 00 \mathrm{~h}\left(29,8 \mathrm{~g} \mathrm{~kg}^{-1}\right)$ comparada a concentração do elemento às 7:00 h $\left(23,8 \mathrm{~g} \mathrm{~kg}^{-1}\right)$ e às 17:00 $\mathrm{h}\left(25,6 \mathrm{~g} \mathrm{~kg}^{-1}\right)$ (Tabela 2). 
A atividade da redutase do nitrato nas plantas a pleno sol às 7:00 $\mathrm{h}$ foi, em média, $73 \%$ maior $(p<0,05)$ em relação àquela determinada nas plantas a MS (50\% de luz). Este comportamento pode ser explicado observando as medidas da taxa de fotossíntese líquida (Figura 7) e da condutância estomática (Figura 8) nesse momento. Na avaliação feita às 7:00 h, em razão da baixa luminosidade (45 $\mu \mathrm{mol}$ quanta $\mathrm{m}^{-2} \mathrm{~s}^{-1}$ sob meia sombra - MS), as médias da fotossíntese líquida (A: $3,50 \mu \mathrm{mol} \mathrm{CO}_{2} \mathrm{~m}^{-2} \mathrm{~s}^{-1}$ ) e da condutância estomática (gs: $0,043 \mathrm{~mol} \mathrm{~m}^{-2} \mathrm{~s}^{-1}$ ) são inferiores àquelas obtidas nas plantas expostas ao sol ( $\mathbf{A}$ : $8,86 \mu \mathrm{mol} \mathrm{CO} \mathrm{C}^{-2} \mathrm{~s}^{-1}$ e gs: $0,149 \mathrm{~mol} \mathrm{~m}^{-2} \mathrm{~s}^{-1}$ ) o que, provavelmente, contribuiu para a menor atividade da $\mathbf{R N}\left(0,335 \mu \mathrm{mol} \mathrm{NO}_{2}^{-} \mathrm{h}^{-1} \mathrm{~g}^{-1}\right.$ de MF), uma vez que esta enzima é pouco ativa quando diminui a concentração de $\mathrm{CO}_{2}$ (Kaiser \& Huber, 2001).

Assumindo que a atividade da RN seja afetada pela quantidade de gás carbônico, pode-se afirmar que a mesma ocorreu devido à elevada resistência estomática ao $\mathrm{CO}_{2}$, aproximadamente, 3,5 vezes superior à resistência medida nas plantas exposta ao sol (PS). Outro aspecto a ser considerado é a concentração de $\mathrm{N}$ foliar a qual era da ordem de $30,7 \mathrm{~g} \mathrm{~kg}^{-1}$ nas folhas das plantas ao sol, teor mais elevado do que àquele determinado nas plantas a meia sombra que foi igual a $23,8 \mathrm{~g} \mathrm{~kg}^{-1}$ (Tabela 2).

A tese de que a atividade da RN (Figura 4) depende da fotossíntese pode ser corroborada por meio das avaliações efetuadas às 7:00 h nas plantas a pleno sol, bem como nas plantas a meia sombra às 12:00 e 17:00 h, uma vez que a atividade dessa enzima acompanhou a taxa de fotossíntese líquida (Figura 7). Entretanto, às 22:00 h os valores dessa variável (RN) também foram elevados, mesmo na ausência da fotossíntese, pois os estômatos das plantas C3 (cafeeiro) e C4 estão fechados à noite. A afirmação de Bachmann et al. (1995), de que a RN pode ser ativada no escuro mediante o fornecimento de açúcar às folhas pode explicar a atividade da referida enzima às 22:00 h. Provavelmente, parte das reservas da energia produzida durante o período 
luminoso seriam utilizadas para ativar a RN (Carelli et al., 1990; Queiroz et al., 1993).

No início do período luminoso (7:00 h) a elevada taxa fotossintética nas plantas PS deve ter diminuido a concentração de $\mathrm{CO}_{2}$ foliar, provocando uma redução no $\mathrm{pH}$ das células guardas estomáticas. Tal condição favorece a atividade catalizadora da enzima transformadora do amido (insolúvel) em sacarose (solúvel) (Dennis, 1987). Dessa maneira, haveria uma maior hidratação das células guardas em razão da solubilidade da sacarose, pelo abaixamento do potencial osmótico, favorecendo a entrada de água e, em consequência, a abertura dos estômatos. Neste experimento, essa afirmação pode ser verificada por meio da condutância estomática (Figura 8), a qual foi superior $(p<0,01)$ nas plantas expostas ao sol comparativamente às plantas a meia sombra.

Estudos desenvolvidos por Talbott \& Zeiger (1998) confirmaram a importância da hipótese do açúcar-amido na abertura estomática, abandonada com a descoberta do papel do K, íon osmoticamente ativo, na regulação da atividade das células guardas. No presente trabalho, o teor foliar de $\mathrm{K}$ na amostra efetuada às 7:00 h nas plantas a pleno sol foi da ordem de $21,4 \mathrm{~g} \mathrm{~kg}^{-1}$, semelhante à concentração determinada nas folhas das plantas à meia sombra $\left(20,7 \mathrm{~g} \mathrm{~kg}^{-1}\right)$ (Tabela 2). Embora não tenha sido avaliado o teor de $\mathrm{K}$ das células guardas, pode-se admitir que a maior condutância estomática verificada às 7:00h deveu-se, em parte, à quantidade de sacarose resultante da transformação do amido e da taxa fotossintética atual (Figura 7). Assim, na presença de maior quantidade de carboidrato, embora não tenha sido quantificado, o mesmo $\left(\mathrm{CH}_{2} \mathrm{O}\right)$ pode ter contribuído para o aumento da pressão de turgor nas células guardas. Esta observação leva em consideração a ausência de limitação hídrica, a qual pode ser confirmada por meio da elevada taxa de transpiração às 7:00 $\mathrm{h}$, tendo sido 2,7 vezes superior nas plantas expostas à irradiação (Figura 9). 


\subsection{Atividade da glutamina sintetase (GS)}

A atividade da glutamina sintetase (GS) diferiu $(p<0,01)$ entre as plantas expostas ao sol e a meia sombra às 7:00 h e 12:00 h (Figura 5). Nas plantas a pleno sol a atividade da (GS) foi da ordem de 78,1 $\mu \mathrm{M} \gamma-\mathrm{GH} \mathrm{h} \mathrm{hg}^{-1} \mathrm{PTS}$, em média, $28 \%$ inferior àquela obtida nas plantas sombreadas $\left(108,1 \mu \mathrm{M} \gamma-\mathrm{GH} \mathrm{h}^{-1}\right.$ $\mathrm{mg}^{-1}$ PTS).

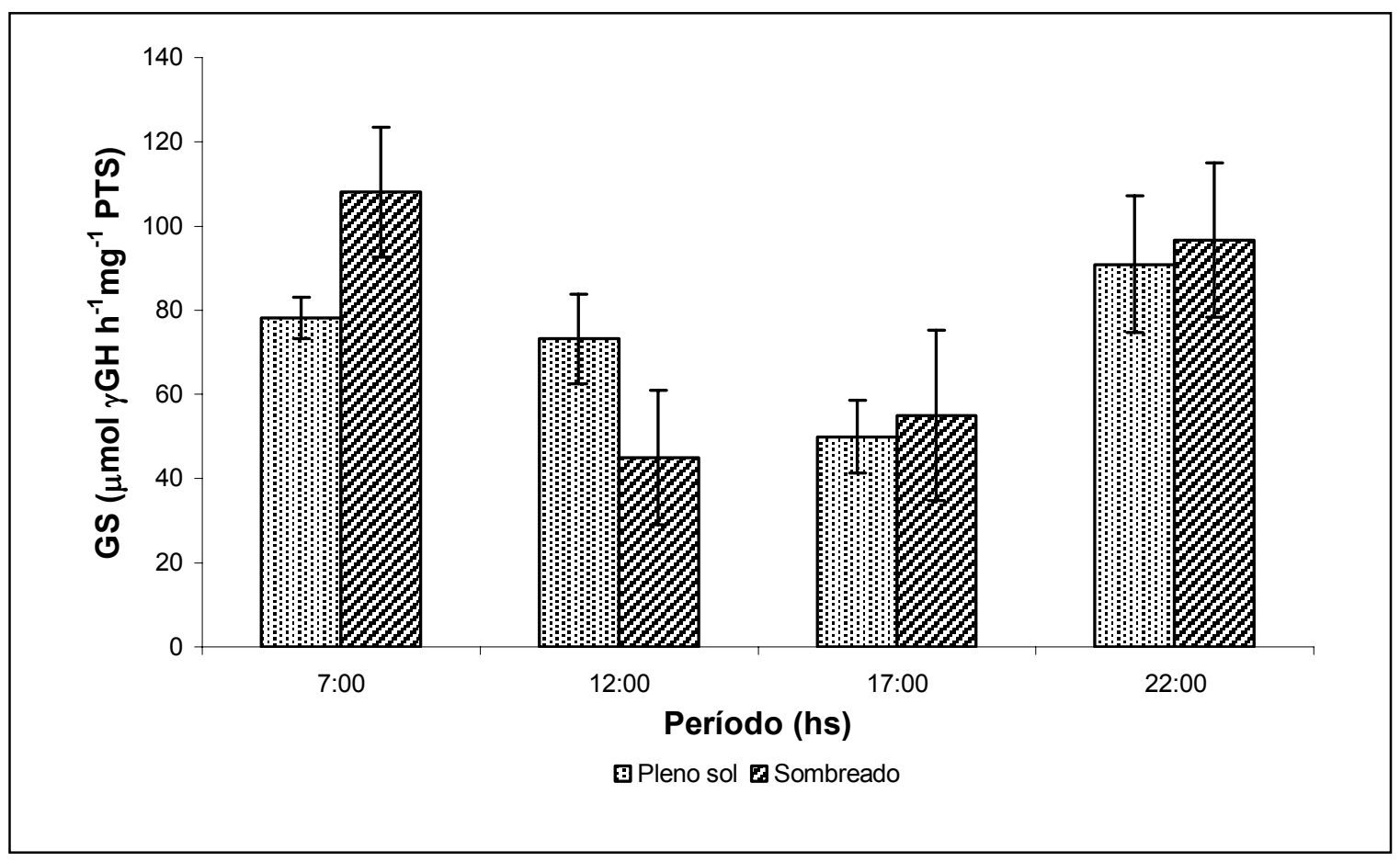

Figura 5 - Médias da atividade da glutamina sintetase (GS) em mudas de Coffea arabica L. cv Obatã IAC 1669-20 cultivadas a pleno sol e a meia sombra às 7:00 h, 12:00 h, 17:00 h e 22:00 h

A elevada atividade da GS nas primeiras horas do período luminoso pode estar relacionada com a atividade da RN no período noturno antecedente, uma vez que o cafeeiro, diferente de outras plantas, apresenta grande atividade da $\mathrm{R}^{-\mathrm{NO}_{3}}{ }^{-}$no escuro (Faleiros et al., 1975; Cordeiro et al., 1984; Carelli et al., 
1990), apresentando um pico no final da noite (Queiroz et al., 1993). Com isso, o amônio formado nesse período seria reassimilado pela GS em compostos orgânicos, para evitar prejuízos às células. De acordo com Matt et al. (2001) a elevada atividade da GS em plantas de fumo cultivadas em meio contendo nitrato de amônio, se deveu ao acúmulo durante o dia e por ter permanecido em níveis elevado a maior parte do período noturno. Fato semelhante ocorreu com o cafeeiro no presente experimento, só que por motivo diferente, uma vez que a atividade enzimática da redutase do nitrato no escuro, forneceu substrato $\left(\mathrm{NH}_{4}{ }^{+}\right)$para a ação da glutamina sintetase na antemanhã.

Os resultados da atividade da GS às 17:00 h e 22:00 h não diferem estatisticamente entre as plantas conduzidas a pleno sol ou expostas a meia sombra (Figura 5). Verifica-se, entretanto, uma tendência crescente da atividade dessa enzima nesse período (17:00 $h$ às 22:00 $h$ ), independentemente, do grau de exposição das plantas à irradiância, passando, em média, de 49,9 $\mu \mathrm{M} \gamma$-GH h${ }^{-1} \mathrm{mg}^{-1}$ PTS para $90,9 \mu \mathrm{M} \gamma-\mathrm{GH} \mathrm{h}^{-1} \mathrm{mg}^{-1}$ PTS nas plantas do tratamento a pleno sol e de 55,0 $\mu \mathrm{M} \gamma-\mathrm{GH} \mathrm{h}^{-1} \mathrm{mg}^{-1}$ PTS para 96,6 $\mu \mathrm{M}$ $\gamma$-GH h $\mathrm{h}^{-1} \mathrm{~m}^{-1}$ PTS naquelas mantidas sob meia sombra (Figura 5).

A flutuação da atividade da GS pode ser explicada pela sua dependência da quantidade de luz e da própria atividade da RN (Tjaden et al., 1995). No período das $17: 00$ às $22: 00 \mathrm{~h}$ foi constatado um aumento na atividade da RN de 0,15 $\mu \mathrm{mol} \mathrm{NO}{ }_{2}^{-} \mathrm{h}^{-1} \mathrm{~g}^{-1}$ de MF para $1,63 \mu \mathrm{mol} \mathrm{NO}{ }_{2}^{-} \mathrm{h}^{-1} \mathrm{~g}^{-1}$ de MF nas plantas expostas a irradiação luminosa e de $0,35 \mu \mathrm{mol} \mathrm{NO}{ }_{2}^{-} \mathrm{h}^{-1} \mathrm{~g}^{-1}$ de MF para $0,69 \mu \mathrm{mol} \mathrm{NO}_{2}^{-} \mathrm{h}^{-1} \mathrm{~g}^{-1}$ de MF naquelas mantidas a meia sombra (Figura 4). Entretanto, os resultados obtidos no período da manhã não corroboram as afirmações de Tjaden et al. (1995), uma vez que às 7:00 $\mathrm{h}$ verificou-se maior atividade da glutamina sintetase $108,1 \mu \mathrm{M} \gamma$-GH h${ }^{-1} \mathrm{mg}^{-1}$ PTS nas plantas à meia sombra e com menor atividade da RN (Figura 4), enquanto às 12:00 $\mathrm{h}$ a maior ação dessa enzima (GS) ocorreu nas plantas expostas ao sol $\left(73,2 \mu \mathrm{M} \gamma-\mathrm{GH} \mathrm{h} \mathrm{hg}^{-1} \mathrm{PTS}\right)$ com menor atividade da RN. Portanto, a atividade da glutamina sintetase em cafeeiro não pode ser explicada apenas 
pelos fatores luminosidade e atividade da $\mathbf{R N}$. A ação da $\mathrm{R}-\mathrm{NO}_{3}{ }^{-}$no período escuro, bem como a intensidade da fotorrespiração no cafeeiro, independentemente da saturação do aparelho fotossintético das plantas expostas ao sol, evidenciado pelos valores da GS às $22: 00 \mathrm{~h}\left(90,9 \mu \mathrm{M} \gamma-\mathrm{GH} \mathrm{h}^{-1}\right.$ $\left.\mathrm{mg}^{-1} \mathrm{PTS}\right)$ e às 12:00 h (73,2 $\left.\mu \mathrm{M} \gamma-\mathrm{GH} \mathrm{h}^{-1} \mathrm{mg}^{-1} \mathrm{PTS}\right)$, fornecem, provavelmente, substrato (amônio) à atividade dessa enzima (GS).

A atividade da $\mathbf{R N}$ às 12:00 $\mathrm{h}$ apresentou, também, diferença significativa $(p<0,01)$ entre os tratamentos estudados, sendo que, sob sombreamento, a atividade da $\mathbf{R N}$ foi, aproximadamente, 2,5 vezes maior que àquela obtida nas plantas ao sol (Figura 4). No entanto, os valores obtidos para a atividade da $\mathbf{G S}$ foram maiores $(p<0,05)$ nas plantas expostas à radiação solar (100 \% luz) em comparação às plantas a meia sombra (50 \% luz). Esse comportamento da atividade da GS, provavelmente, está relacionado com a presença de amônio proveniente da fotorrespiração, visto que o cafeeiro a pleno sol às 12:00 $\mathrm{h}$ encontrava-se sob intensa radiação fotossinteticamente ativa (PAR: $1.302 \mu \mathrm{mol} \mathrm{m} \mathrm{m}^{-2} \mathrm{~s}^{-1}$ ) e elevada temperatura foliar $40,7^{\circ} \mathrm{C}$. Nesse horário $(12: 00 \mathrm{~h})$, a combinação dos resultados como: baixa condutância estomática (gs: $0,06 \mathrm{~mol} \mathrm{~m}^{-2} \mathrm{~s}^{-1}$ ), menor taxa de transpiração (E: $3,90 \mathrm{~mol} \mathrm{H}_{2} \mathrm{O}$ $\left.\mathrm{m}^{-2} \mathrm{~s}^{-1}\right)$ e de fotossíntese líquida $\left(\mathbf{A}: 7,60 \mu \mathrm{mol} \mathrm{CO}_{2} \mathrm{~m}^{-2} \mathrm{~s}^{-1}\right)$, juntamente com a reduzida atividade da redutase do nitrato ( $R N$ : $0,26 \mu \mathrm{mol} \mathrm{NO}_{2} \mathrm{~h}^{-1} \mathrm{~g}^{-1}$ (MF), comparativamente às médias verificadas nas plantas a meia sombra, não justificam a elevada atividade da GS determinada às 12:00 h. Esse comportamento pode ser explicado pelo aumento da disponibilidade de amônio originado da fotorrespiração que ocorre nas plantas de cafeeiro expostas ao sol, superando a rota normal, quando o substrato $\left(\mathrm{NH}_{4}{ }^{+}\right)$advém da atividade da redutase do nitrato.

Outra explicação pode ser dada por meio do teor de proteína total solúvel (PTS) determinado às 12:00 h, o qual diferiu $(p<0,05)$ entre as plantas a pleno sol (0,482 mg PTS $\left.\mathrm{g}^{-1} \mathrm{MF}\right)$ e a meia sombra (0,318 $\left.\mathrm{mg}^{\mathrm{PTS}} \mathrm{g}^{-1} \mathrm{MF}\right)$ (Figura 6). Essa diferença pode estar relacionada com o decréscimo na 
atividade da GS ocorrido no mesmo horário (Figura 5). Häusler et al. (1994) estudaram a fotossíntese em folhas de cevada que apresentavam reduzida atividade da glutamina sintetase. De acordo com os autores houve um decréscimo na atividade tanto da GS quanto da Fd - GOGAT o que implicou na diminuição na quantidade de proteína foliar. Para os autores, a proteína total por unidade de área foliar decresceu $10 \%$ a $17 \%$ quando a atividade da GS caiu $50 \%$. Os dados do presente trabalho evidenciaram uma redução de aproximadamente $38 \%$ nos teores de PTS entre as determinações efetuadas às 7:00 h e 12:00 h, nas plantas conduzidas à meia sombra (MS). Nesse período, a atividade da GS decresceu, em média, $58 \%$ passando de 108,1 $\mu \mathrm{M}$ $\gamma$-GH h${ }^{-1} \mathrm{mg}^{-1}$ PTS para 44,5 $\mu \mathrm{M} \gamma-\mathrm{GH} \mathrm{h}^{-1} \mathrm{mg}^{-1}$ PTS (Figura 6).

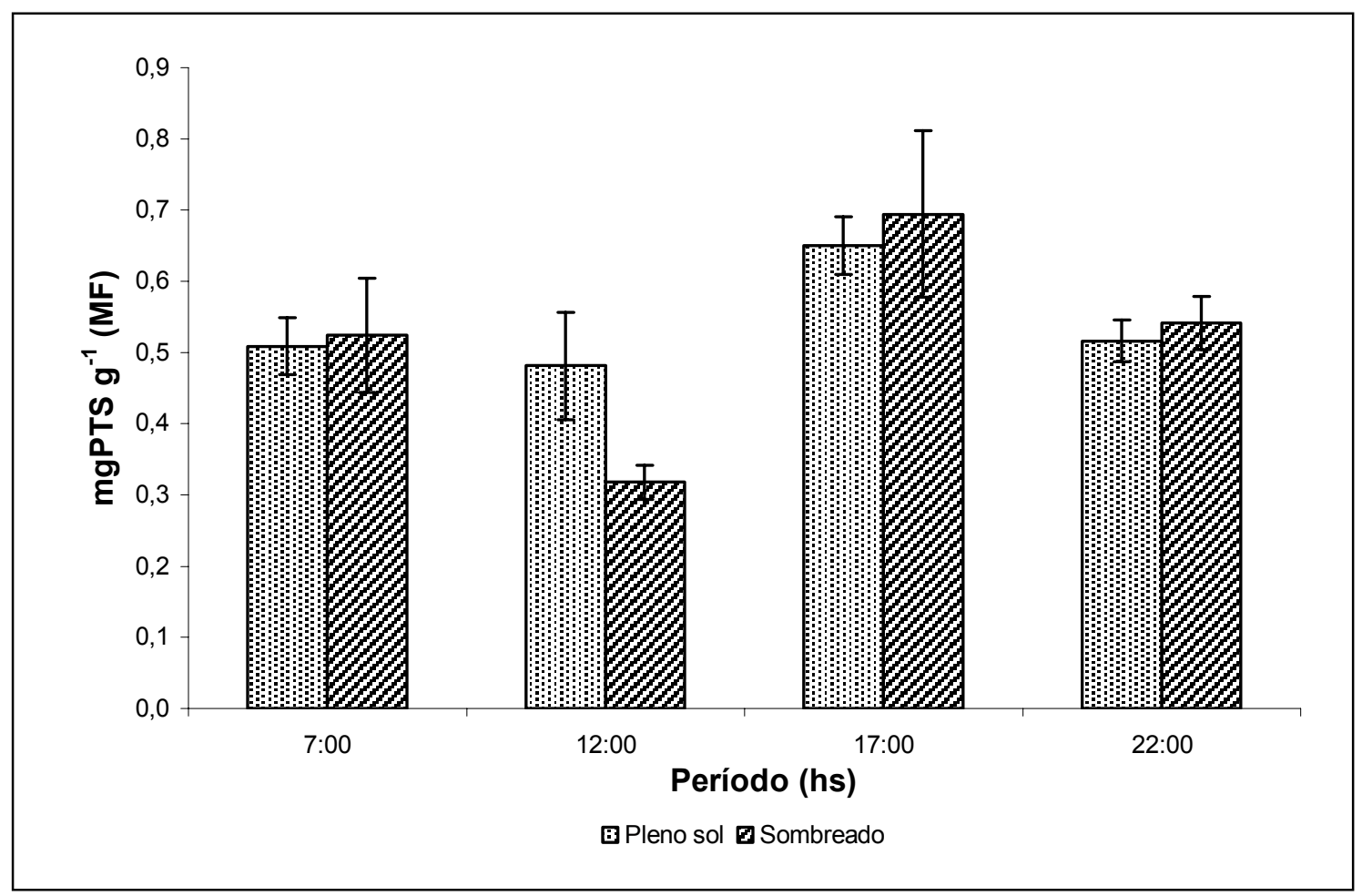

Figura 6 - Médias de proteína total solúvel (PTS) em mudas de Coffea arabica L. cv Obatã IAC 1669-20 cultivadas a pleno sol e a meia sombra às 7:00 h, 12:00 h, 17:00 h e 22:00 h 


\subsection{Atributos ecofisiológicos}

Neste item serão discutidos os atributos fisiológicos como a condutância estomática (gs), taxa de fotossíntese líquida (A), taxa de transpiração (E), bem como aqueles ligados ao clima, ou seja, a temperatura atmosférica (Ta), a temperatura foliar (Tf) e a radiação fotossinteticamente ativa (PAR).

A taxa de fotossíntese líquida $(\mathbf{A})$ diferiu $(p<0,05)$ entre os tratamentos (nível de exposição à radiação) em todos os intervalos estudados (Tabela 1). Às 7:00 $\mathrm{h}$ a atividade fotossintética foi maior nas plantas do tratamento PS $(8,86$ $\mu \mathrm{mol} \mathrm{CO}_{2} \mathrm{~m}^{-2} \mathrm{~s}^{-1}$ ) apresentando, em média, valores 2,5 vezes superiores em relação às plantas do tratamento $\mathrm{MS}\left(3,50 \mu \mathrm{mol} \mathrm{CO}_{2} \mathrm{~m}^{-2} \mathrm{~s}^{-1}\right)$. Estes resultados estão correlacionados com as médias obtidas para gs (Figura 8) e E (Figura 9), uma vez que, neste horário, nas plantas a meia sombra, os estômatos estavam praticamente fechados $\left(0,04 \mathrm{~mol} \mathrm{~m}^{-2} \mathrm{~s}^{-1}\right)$ e com baixíssima taxa transpiratória $\left(0,50 \mathrm{mmol} \mathrm{m}^{-2} \mathrm{~s}^{-1}\right)$ (Tabela 1).

Tabela 1. Médias da taxa de fotossíntese líquida (A), condutância estomática (gs), taxa de transpiração (E), temperatura atmosférica (Ta), temperatura foliar (Tf) e radiação fotossinteticamente ativa (PAR), nas mudas de Coffea arabica L. cv Obatã IAC 1669-20 cultivadas a pleno sol (PS) e a meia sombra (MS).

\begin{tabular}{|c|c|c|c|c|c|c|}
\hline \multirow{2}{*}{ Variáveis } & \multicolumn{2}{|c|}{$7: 00 \mathrm{~h}$} & \multicolumn{2}{|c|}{$12: 00 \mathrm{~h}$} & \multicolumn{2}{|c|}{$17: 00 \mathrm{~h}$} \\
\hline & PS & MS & PS & MS & PS & MS \\
\hline $\mathbf{A}\left(\mu \mathrm{mol} \mathrm{CO}_{2} \mathrm{~m}^{-2} \mathrm{~s}^{-1}\right)$ & $8,86 a^{1}$ & $3,50 b^{1}$ & $7,60 b^{1}$ & $12,08 a^{1}$ & $6,38 b^{1}$ & $11,64 a^{1}$ \\
\hline gs $\left(\mathrm{mol} \mathrm{m} \mathrm{m}^{-2} \mathrm{~s}^{-1}\right)$ & $0,15 a^{1}$ & $0,04 b^{1}$ & $0,08 b^{2}$ & $0,21 a^{2}$ & $0,05^{\mathrm{ns}}$ & $0,06^{\mathrm{ns}}$ \\
\hline$E\left(m m o l ~ m^{-2} \mathrm{~s}^{-1}\right)$ & $1,37 a^{1}$ & $0,50 b^{1}$ & $3,90 b^{1}$ & $7,80 a^{1}$ & $1,87^{\mathrm{ns}}$ & $1,12^{\mathrm{ns}}$ \\
\hline $\operatorname{Ta}\left({ }^{\circ} \mathrm{C}\right)$ & $27,0 a$ & $27,8 a$ & $38,8 a$ & $41,3 b$ & $36,9 a$ & $30,7 b$ \\
\hline $\operatorname{Tf}\left({ }^{\circ} \mathrm{C}\right)$ & $26,1 a$ & $26,9 a$ & $40,7 c$ & $39,6 c$ & $36,6 a$ & $29,9 c$ \\
\hline PAR $\left(\mu \mathrm{mol} \mathrm{m} \mathrm{m}^{-2} \mathrm{~s}^{-1}\right)$ & 90 & 45 & 1.302 & 616 & 450 & 220 \\
\hline
\end{tabular}

significativo a $1 \%$ de probabilidade, ${ }^{2}$ significativo a $5 \%$ e ${ }^{\text {ns }}$ não significativo 
Os valores obtidos para a transpiração $(E)$ às $7: 00 \mathrm{~h}$ diferiram significativamente, com as plantas expostas ao sol trocando maior quantidade de gases $\left(\mathrm{CO}_{2}\right.$ e vapor d'água) com a atmosfera $\left(1,37 \mathrm{mmol} \mathrm{m}^{-2} \mathrm{~s}^{-1}\right)$ comparativamente às plantas conduzida à meia sombra, em razão da maior abertura estomática $\left(0,15 \mathrm{~mol} \mathrm{~m}^{-2} \mathrm{~s}^{-1}\right)$ (Figura 8). Não foi constatada diferença $(p>0,05)$ em relação à temperatura do ambiente $(\mathbf{T a})$ e a temperatura foliar (Tf) entre os tratamentos e dentro de cada tratamento (Tabela 1) na avaliação efetuada às 7:00 h.

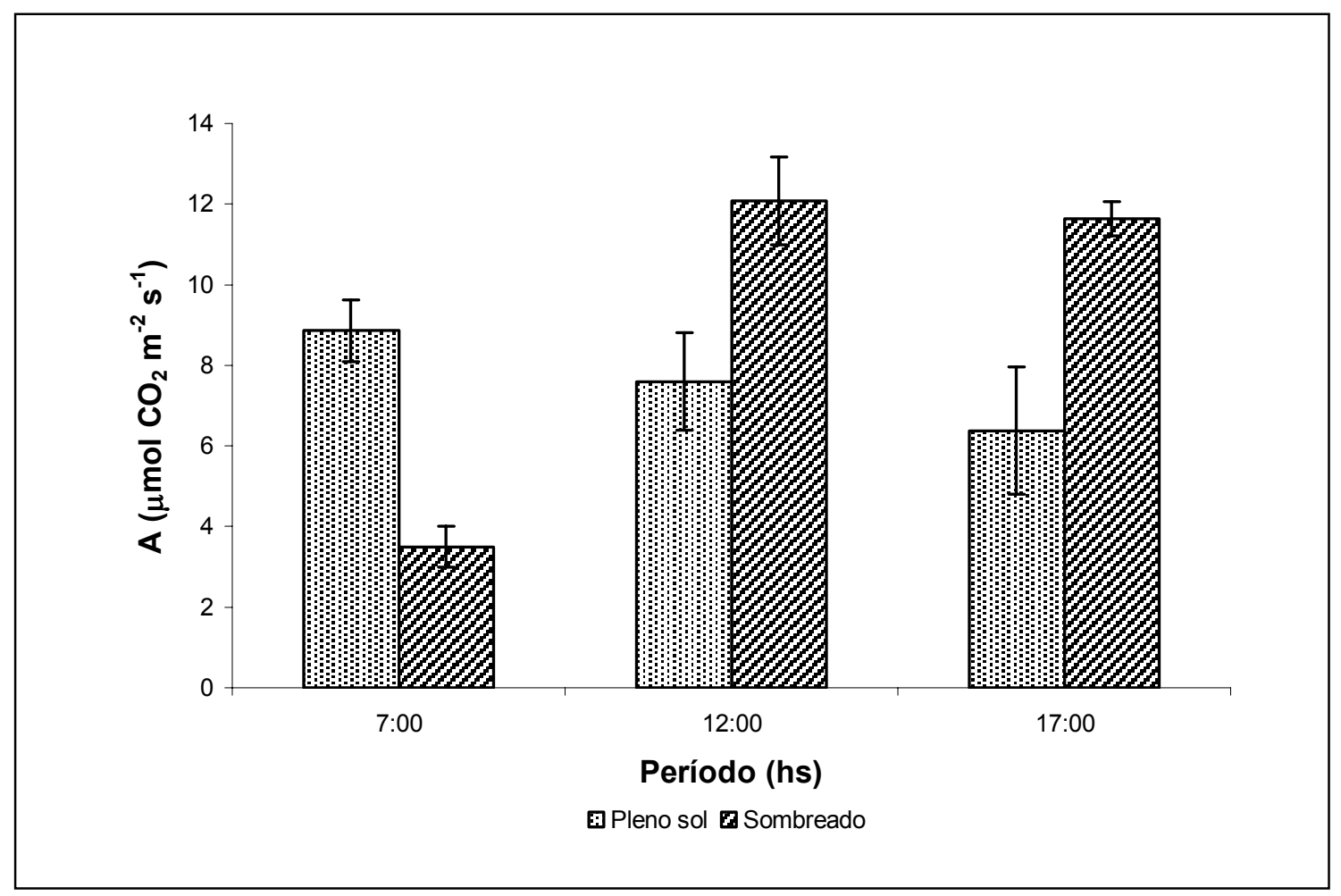

Figura 7 - Médias da taxa de fotossíntese líquida (A) determinada em mudas de Coffea arabica L. cv Obatã IAC 1669 -20 cultivadas a pleno sol e a meia sombra às 7:00 $\mathrm{h}, 12: 00 \mathrm{~h}$ e 17:00 $\mathrm{h}$

No horário das $12: 00 \mathrm{~h}$ nas plantas a pleno sol as médias de $\mathbf{A}$ eram semelhantes em relação àquelas obtidas às 7:00 $\mathrm{h}$, apresentando uma 
tendência decrescente (Tabela 1). Entretanto, nas plantas do tratamento a MS a média obtida para $\mathbf{A}$ foi igual a $12,0 \mu \mathrm{mol} \mathrm{CO}_{2} \mathrm{~m}^{-2} \mathrm{~s}^{-1}$ diferindo $(p<0,05)$ em relação às plantas do tratamento PS $\left(7,60 \mu \mathrm{mol} \mathrm{CO}_{2} \mathrm{~m}^{-2} \mathrm{~s}^{-1}\right)$. Em condições de meia sombra (MS) o cafeeiro apresentou maior gs $\left(0,21 \mathrm{~mol} \mathrm{~m}^{-2} \mathrm{~s}^{-1}\right)$ e $\mathbf{E}(7,80$ $\mathrm{mmol} \mathrm{m} \mathrm{m}^{-2} \mathrm{~s}^{-1}$ ), indicando uma atividade fisiológica mais confortável às plantas em comparação às plantas a pleno sol, uma vez que, nesse ambiente, a irradiância era muito elevada $\left(1.302 \mu \mathrm{mol} \mathrm{m} \mathrm{m}^{-2} \mathrm{~s}^{-1}\right)$, superior ao valor considerado saturante $\left(600 \mu \mathrm{mol} \mathrm{m} \mathrm{m}^{-2} \mathrm{~s}^{-1}\right)$ ao aparelho fotossintético do cafeeiro (Kumar e Tieszen, 1980). Neste horário $(12: 00 \mathrm{~h})$, houve diferença significativa $(p<0,05)$ em relação à Ta e Tf entre e dentro de cada tratamento (Tabela 1).

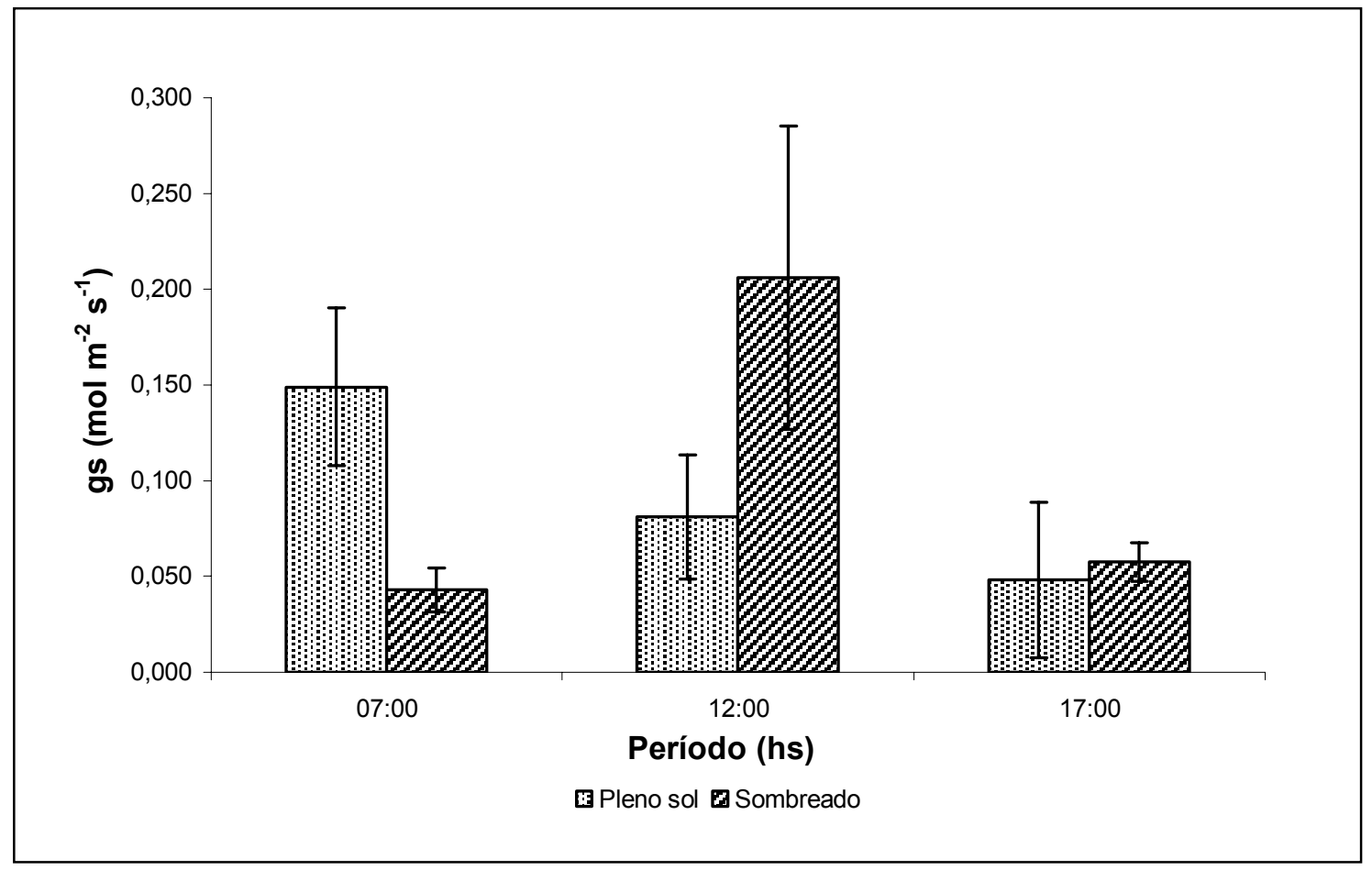

Figura 8 - Médias da condutância estomática (gs) em mudas de Coffea arabica L. cv Obatã IAC 1669-20 cultivadas a pleno sol e a meia sombra às 7:00 h, 12:00 h e 17:00 h 
No período estudado a temperatura foliar foi sempre inferior à temperatura do ar, exceto ao meio dia no tratamento PS. No tratamento MS, apesar da Ta ter superado a temperatura observada no tratamento PS a Tf foi mais baixa. Esta elevação na temperatura da folha no tratamento PS, proporcionada pela elevada irradiância e pela redução da gs e $\mathbf{E}$ influenciou a redução das médias de $\mathbf{A}$ em relação às médias verificadas no tratamento MS. Nas regiões tropicais quando a temperatura atmosférica atinge valores da ordem de $30{ }^{\circ} \mathrm{C}$ a $35^{\circ} \mathrm{C}$ a temperatura foliar pode chegar a $40{ }^{\circ} \mathrm{C}$ a $45^{\circ} \mathrm{C}$ (Kumar e Tiezen, 1980). Estes autores verificaram que A permaneceu relativamente elevada sob $30^{\circ} \mathrm{C}$ a $35^{\circ} \mathrm{C}$, apresentando fotossíntese líquida nula quando a $\mathrm{Tf}$ chegou a $45^{\circ} \mathrm{C}$.

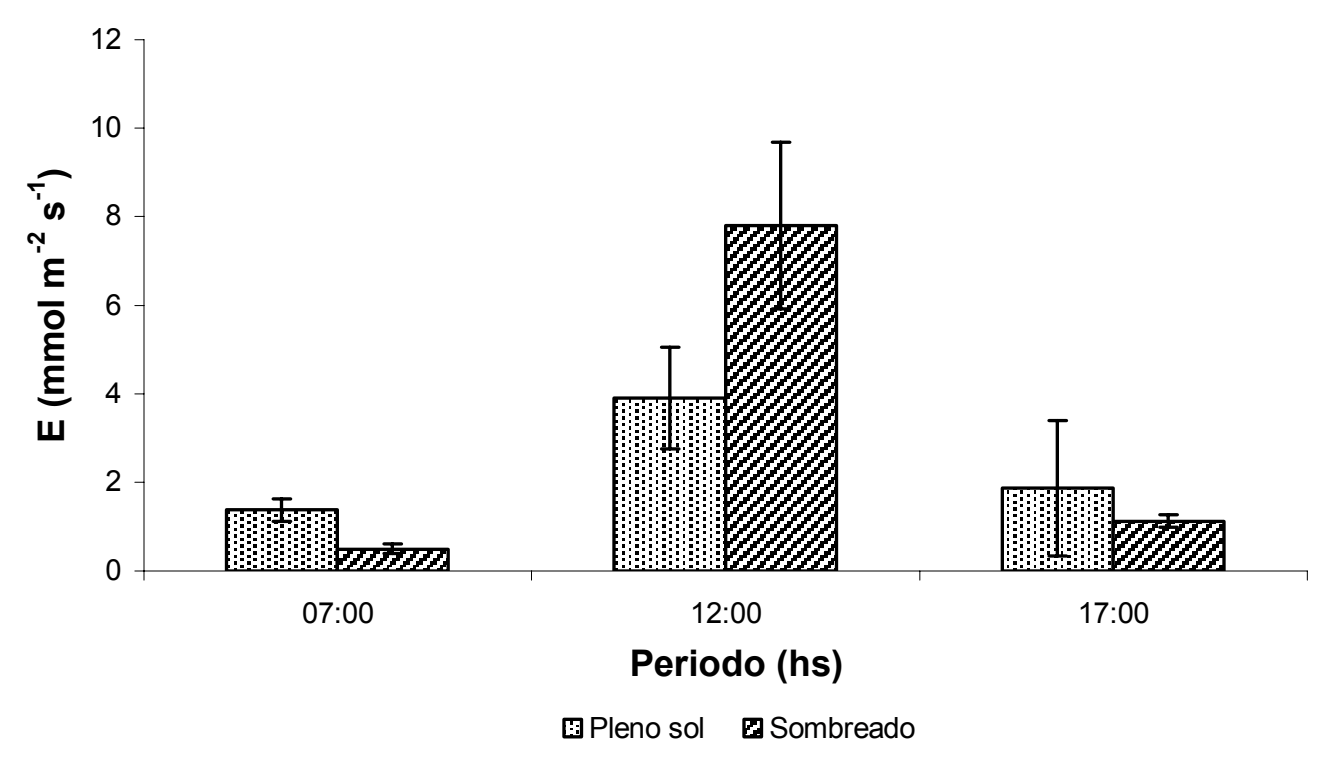

Figura 9 - Médias da taxa de transpiração (E) em mudas de Coffea arabica L. cv Obatã IAC 1669-20 cultivadas a pleno sol e a meia sombra às 7:00 h, 12:00 h e 17:00 h 
A taxa de fotossíntese líquida às $17: 00 \mathrm{~h}$ praticamente se manteve inalterada nas plantas do tratamento MS em relação à avaliação efetuada às 12:00 h. Entretanto, observa-se uma tendência decrescente nos valores de A, nas plantas do tratamento a pleno sol (PS), desde as primeira horas do dia até ao entardecer (Figura 7). Comportamento semelhante pode ser observado em relação à gs nas plantas do mesmo tratamento - expostas a radiação solar (Figura 8).

\subsection{Resultado da análise química foliar}

Com relação aos resultados da análise química foliar verificou-se variações nos teores de nutrientes nos momentos avaliados. O teor de $\mathbf{N}$, tanto nas plantas dos tratamentos PS quanto nas plantas do tratamento MS variou ao longo do dia, semelhante ao comportamento apresentado pela atividade da enzima RN. Nas plantas do tratamento PS, os teores decresceram passando de $30,7 \mathrm{~g} \mathrm{~kg}^{-1}$ para $25,3 \mathrm{~g} \mathrm{~kg}^{-1}$ e $20,9 \mathrm{~g} \mathrm{~kg}^{-1}$ às 7:00 h, 12:00 h e 17:00 h nessa ordem, aumentando, na seqüência, para uma concentração igual a $30,8 \mathrm{~g} \mathrm{~kg}^{-1}$ às 22:00 $\mathrm{h}$ (Tabela 2).

Tabela 2. Resultados da análise foliar das amostras utilizadas na determinação da atividade da redutase do nitrato em mudas de Coffea arabica L. cv Obatã IAC 1669-20 cultivadas a pleno sol e a meia sombra

\begin{tabular}{|c|c|c|c|c|c|c|c|c|c|c|c|}
\hline \multirow{2}{*}{ Tratamentos } & \multirow{2}{*}{ horas } & $\mathrm{N}$ & $P$ & $\mathrm{~K}$ & $\mathrm{Ca}$ & $\mathrm{Mg}$ & $S$ & $B$ & $\mathrm{Cu}$ & $\mathrm{Mn}$ & $\mathrm{Zn}$ \\
\hline & & \multicolumn{6}{|c|}{$\mathrm{g} \mathrm{kg}^{-1}$} & \multicolumn{4}{|c|}{$\mathrm{mg} \mathrm{kg}^{-1}$} \\
\hline \multirow{4}{*}{ Pleno Sol } & $07: 00$ & 30,7 & 2,9 & 21,5 & 10,4 & 3,3 & 0,8 & 102 & 13,4 & 136 & 25,8 \\
\hline & $12: 00$ & 25,3 & 2,5 & 18,4 & 11,8 & 3,0 & 0,8 & 81 & 12,3 & 158 & 18,9 \\
\hline & $17: 00$ & 20,9 & 2,3 & 18,4 & 12,3 & 3,0 & 0,8 & 89 & 7,5 & 144 & 12,2 \\
\hline & $22: 00$ & 30,8 & 2,7 & 19,1 & 10,8 & 3,1 & 1,1 & 137 & 9,3 & 140 & 18,4 \\
\hline \multirow{4}{*}{ Meia sombra } & 07:00 & 23,8 & 2,2 & 20,7 & 10,8 & 2,7 & 1,1 & 69 & 13,0 & 152 & 22,7 \\
\hline & $12: 00$ & 29,8 & 2,4 & 21,4 & 13,0 & 3,2 & 1,3 & 67 & 12,3 & 145 & 19,1 \\
\hline & $17: 00$ & 25,6 & 2,1 & 21,4 & 12,7 & 2,8 & 1,3 & 74 & 7,5 & 141 & 17,2 \\
\hline & $22: 00$ & 28,6 & 2,2 & 19,9 & 11,4 & 2,9 & 0,9 & 66 & 19,9 & 101 & 23,7 \\
\hline
\end{tabular}


Nas plantas do tratamento a meia sombra (MS) a concentração de $\mathbf{N}$ variou de $23,8 \mathrm{~g} \mathrm{~kg}^{-1}$ às $7: 00 \mathrm{~h}$ para $29,8 \mathrm{~g} \mathrm{~kg}^{-1}$ às $12: 00 \mathrm{~h}$, decrescendo às 17:00 $\mathrm{h}$ para $25,6 \mathrm{~g} \mathrm{~kg}^{-1}$, aumentando, novamente, às $22: 00 \mathrm{~h}$ para $28,6 \mathrm{~g} \mathrm{~kg}^{-1}$ (Tabela 2).

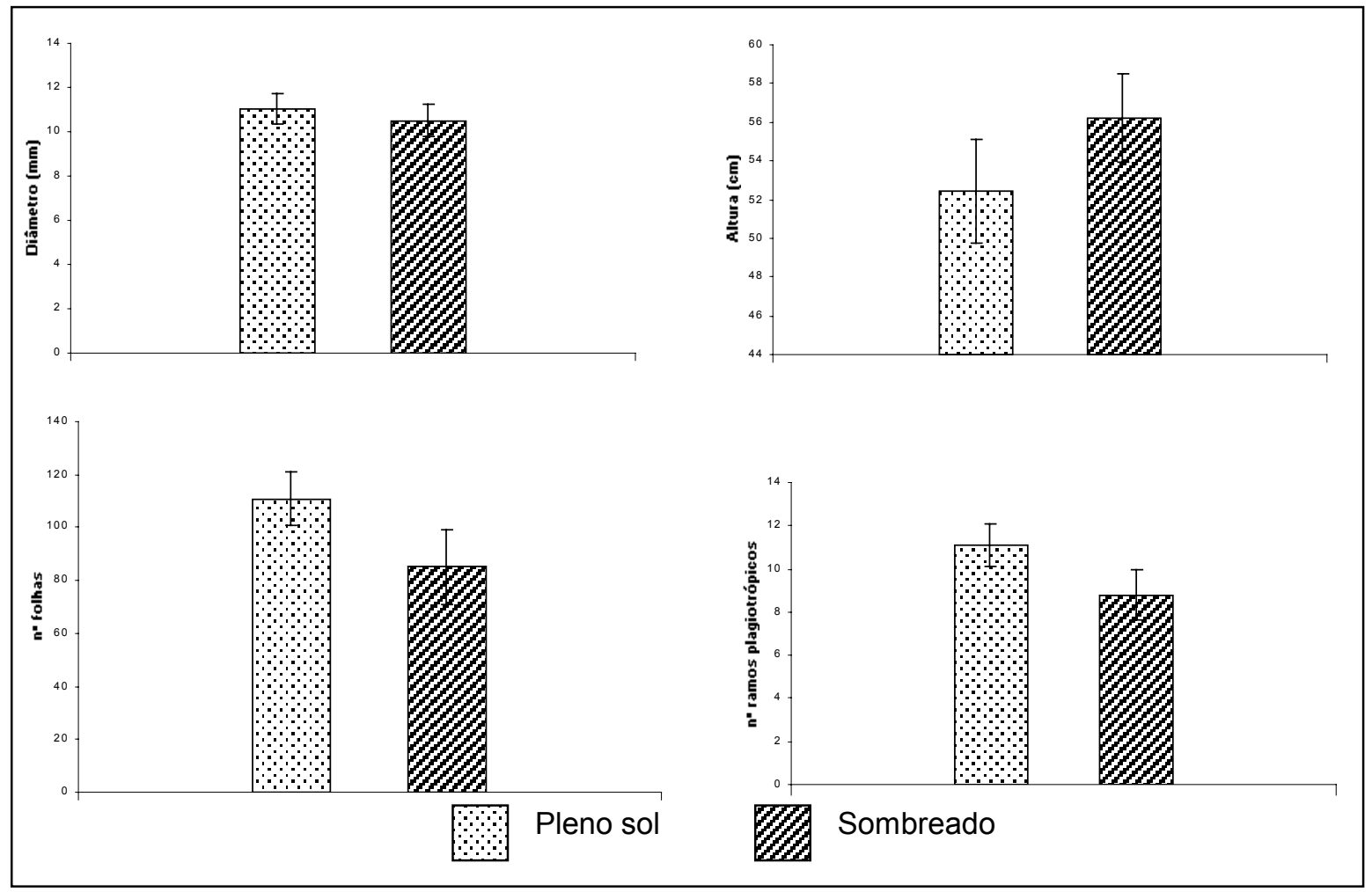

Figura 10 - Médias do diâmetro do caule (DC), altura da planta (H), número de folhas (NF) e número de ramos plagiotrópicos (NRP) das mudas de Coffea arabica L. cv Obatã IAC 1669-20 cultivadas a pleno sol e a meia sombra

Os resultados obtidos para a GS (Figura 5) evidenciam que no intervalo entre 7:00 h e 12:00 h a enzima apresentou elevada atividade, ao passo que a RN decresceu. A atividade da GS produz aminoácidos que podem ser utilizados pela folha ou exportados para os drenos mais próximos como as folhas novas e as partes em crescimento dos ramos plagiotrópicos (ápice), ao passo que uma 
menor atividade da $\mathbf{R N}$ pode significar uma queda na entrada de nitrogênio inorgânico na folha. Esta redução nos teores de nitrogênio, provavelmente, se justifica em razão do aumento do número de folhas e de ramos plagiotrópicos, conforme ocorreu nas plantas do tratamento PS (Figura 10).

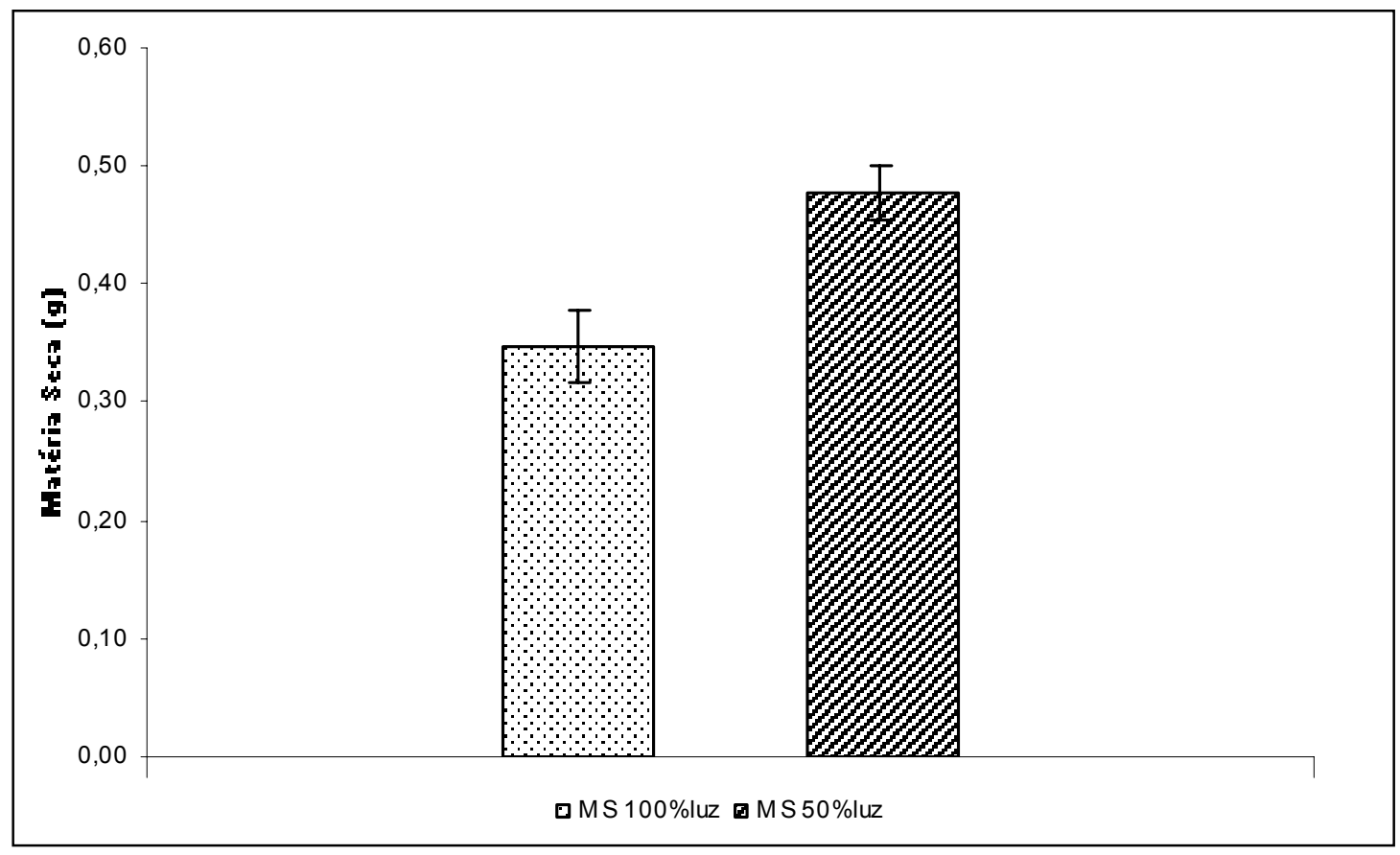

Figura 11 - Médias da matéria seca das folhas (MS) de Coffea arabica L. cv Obatã IAC 1669-20 cultivadas a pleno sol e a meia sombra

A maior produção de fitomassa, estimada por meio da matéria seca das folhas da muda de café, reflete as condições ecofisiológicas obtidas no experimento. De acordo com os resultados apresentados na Figura 11, as folhas das mudas conduzidas a meia sombra apresentaram maior quantidade de massa do que as plantas expostas ao sol em consequência da superioridade da taxa fotossintética durante a maior parte do período luminoso (Figura 7). Esta observação pode ser explicada, também, pelo menor gasto de energia para a assimilação do nitrogênio via redutase do nitrato durante o período 
noturno. Do exposto, pode-se afirmar que as mudas de café, na fase de viveiro, apresentam maior crescimento e desenvolvimento vegetativo quando expostas a meia sombra (50\% de luz). 


\section{CONCLUSÕES}

* O nível de exposição à luminosidade altera a atividade da redutase do nitrato (RN), cujo valor foi menor nas plantas a pleno sol às 12:00 h e 17:00 $\mathrm{h}$.

* A saturação lumínica e a maior temperatura foliar em relação ao ambiente, às $12: 00 \mathrm{~h}$, diminuiu as trocas gasosas $\left(\mathrm{CO}_{2}\right.$ e vapor d'água) e a atividade da $\mathbf{R N}$.

Ao longo do período luminoso, independentemente do nível de exposição à luminosidade, decresceu a atividade da glutamina sintetase (GS).

* A disponibilidade de amônio proveniente da ação da RN no período noturno elevou a atividade da GS, enquanto a fotorrespiração, por hipótese, forneceu o substrato $\left(\mathrm{NH}_{4}{ }^{+}\right)$para a atividade dessa enzima (GS) nas plantas a pleno sol ao meio dia.

* A inibição da redutase do nitrato (RN) no cafeeiro propordionada pela fotorrespiração se dá, por hipotese, em resposta a produção de glutamina por meio da atividade da glutamina sintetase (GS). 


\section{REFERÊNCIAS BIBLIOGRÁFICAS}

ABREU, M.F. de; ABREU, C.A.; ANDRADE, J.C. de. Determinação de boro em água quente, usando aquecimento com microonda. In: RAIJ, B. van; ANDRADE, J.C. de; CANTARELLA, H.; QUAGGIO, J.A. (Ed.). Análise química para avaliação da fertilidade de solos tropicais. Campinas: Instituto Agronômico, 2001. p.231-239.

ALVES, J.D.; CORDEIRO, A.T.; RENA, A.B. Relações entre fotossíntese, resistência difusiva e variação circadiana da redutase do nitrato em Coffea arabica L. In: CONGRESSO BRASILEIRO DE PESQUISAS CAFEEIRAS, 12., Caxambu, 1985. Anais. Rio de Janeiro: MMIC;IBC, 1985. p.142-145.

ANTHONY, F.; BERTRAND, B.; QUIROS, O. et al. Genetic diversity of wild coffee (Coffea arabica L.) using molecular markers. Euphytica, v.118, n.1, p.53-65, 2001.

BACHMANN, M.; McMICHAEL, R.N.; HUBER, J.L. et al. Partial purification and characterization of a calcium - dependent protein kinase and an inhibitor protein required for the activation of spinach leaf nitrate reductase. Plant Physiology, v.108, p.1083-1091, 1995. 
BECKER, T.W.; CABOCHE, M.; CARRAYOL, E. et al. Nucleotide-sequence of a tobacco cDNA-encoding plastidic glutamine synthetase and light-inducibility organ specificity and diurnal rhythmicity in the expression of the corresponding genes of tobacco and tomato. Plant Molecular Biology, v.19, n.3, p.367-379, June 1992.

BEEVERS, L.; HAGEMAN, R.H. Nitrate reduction in higher plants. Annual Review of Plant Physiology, v.20, p.495-522, 1969.

BEEVERS, L.; STOREY, R. Glutamato synthetase in developing cotyledons of Pisum sativum. Plant Physiology, v. 57, p.862-866, 1976.

BENNETT, M.J.; CULLIMORE, J.V. Glutamine-synthetase isoenzymes of Phaseolus vulgaris L. subunit composition in developing root nodules and plumules. Planta, v.179, n.4, p.433-440, 1989.

BERTHAUD, J.; CHARRIER, A. Genetic resources of Coffea. In: CLARKE, R. J.; MACRAE, R. (Ed.). Coffee. London: Elsevier Applied Science, 1988. v. 4, p.1-42.

BLOOM, A.J. Nitrogen as a limiting factor: crop acquisition of ammonium and nitrate. In: JACKSON, L.E.(Ed.). Ecology in agriculture. San Diego: Academic Press, 1997. p.145-172.

BLOOM, A.J.; SUKRAPANNA, S.S.; WARNER, R.L. Root respiration associated with ammonium and nitrate absorption and assimilation by barley. Plant Physiology, v.99, p. 1294-1301, 1992. 
BRADFORD, M.M. A rapid sensitive method for the quantitation of microgram quantities of protein utilizing the principle of protein-dye-binding. Analytical Biochemistry, v.72, p.248-254, 1976.

BRIDSON, D.M. Additional notes on Coffea (Rubiaceae) from Tropical East Africa. Kew Bulletin, v.49, n.2, p.331-342, 1994.

BRIDSON, D.M.; VERDCOURT, B. Flora of tropical east Africa. In: POLHILL, R. M. (Ed.). Rubiaceae (Part 2). Rotterdam: Balkema, 1988. 727p.

CAI, X.; WONG, P.P. Subunit composition of glutamine synthetase isoenzymes from root nodules of bean (Phaseolus vulgaris L.). Plant Physiology, v. 91, p.1056 -1062, 1989.

CAMPBELL, W.H. Nitrate reductase structure function and regulation on bridging to gap between biochemistry and physiology. Annual Review Plant Physiology Plant Molecular Biology, v.50, p.277-303, 1999.

CANNEL, M.G.R. Physiology of coffee crop. In: CLIFFORD, N.M.; WILSON, K.C. Coffee: botany, biochemistry and production beans and beverage. London: Croom Helm, 1985. p.108-134.

CARELLI, M.L.C. Estudo do processo de redução do nitrato durante o desenvolvimento inicial e no estádio reprodutivo de plantas de café (Coffea arabica L.). Campinas, 1987. 111p. Tese (Doutorado) - Universidade Estadual de Campinas.

CARELLI, M.L.C.; FAHL, J.L.; MAGALHÃES, A.C. Redução de nitrato em plantas jovens de café cultivadas em diferentes níveis de luz e de nitrogênio. Bragantia, v.49, n.1, p.1-9, 1990. 
CARELLI, M.L.C.; FAHL, J.I.; PEZZOPANE, J.R.M. Densidade de fluxo de seiva em plantas de café (Coffea arabica L.) em diferentes regimes de água e de irradiância. In: SIMPOSIO DE PESQUISA DE CAFÉS DO BRASIL, 1., Poços de Caldas, 2000. Resumos expandidos. Brasilia, EMBRAPA Café e Minasplan, 2000. p.42-45.

CARR, M.K.V. The water relations and irrigation requeriments of coffee. Experimental Agriculture. v.37, n.1, p.1-36. 2001.

CARVALHO, A. Distribuição geográfica e classificação bôtanica do gênero Coffea com referência especial à espécie Arabica. Separata dos Boletins da Superintendência dos Serviços do Café, p. 226-230, São Paulo, 1946.

CARVALHO, F. Estudo da atividade da redutase de nitrato em mudas de cafeeiro (Coffea arabica L.) cultivadas a meia sombra e a pleno sol sob as formas nítricas e amoniacal de adubação nitrogenada. In: CONGRESSO BRASILEIRO DE PESQUISAS CAFEEIRAS, 3., Curitiba,1975. Resumos. Curitiba/IBC;GERCA, 1975. p.208-210.

COCK, J.M.; BROCK, J.W.; WATSON, A.T. et al. Regulation of glutamine synthetase genes in leaves of Phaseolus vulgaris. Plant Molecular Biology, v.17, p. 761-771, 1991.

CORDEIRO, A.T.; RENA, A.B.; MENDES, L.F. Atividade da redutase do nitrato em plantas jovens e adultas de Coffea arabica L., à luz e na obscuridade. In: CONGRESSO BRASILEIRO DE PESQUISAS CAFEEIRAS, 11., Curitiba, 1984. Anais. Rio de Janeiro/ MIC;IBC, 1984. p.77-79.

CRAWFORD, N.M. Nitrate: nutrient and signal for plant growth. The Plant Cell, v.7, p. 859-868, 1995. 
CRAWFORD, N.M.; KAHN, M.L.; LEUSTEK, T. et al. Nitrogen and sulfur In: BUCHANAN, B.; GRUISSEM, W.; JONES, R. (Ed.). Biochemistry \& molecular biology of plants. Rockville: American Society of Plant Physiologists, 2000. Cap. 16, p. 786-849.

CROCOMO, O.J. Assimilação do nitrogênio pelas plantas. In: FERRI, M.G. (Ed.). Fisiologia Vegetal. São Paulo: EPU, 1985. p.181-209.

CULLIMORE, J.V.; LARA, M.; LEA, P.J. et al.Purification and properties of two forms of glutamine synthetase form plant fraction of Phaseolus root nodules. Planta, v.157, p. 245-253, 1983.

DAMATTA, F.M.; MAESTRI, M. Photo inhibition and recovery of photosynthesis in Coffea arabica and Coffea canephora. Photosynthetica, v.34, p.439-446. 1997.

DAMATTA F. M.; RENA, A.B. Ecofisiologia de cafezais sombreados e a pleno sol. In. ZAMBOLIM, O estado da arte de tecnologias na produção de café. Viçosa:UFV, Departamento de Fitopatologia, 2002. p.93-135.

DENNIS, E.J. Micronutrientes: a função das enzimas. In: DENNIS, E.J Micronutrientes. Campinas: Fundação Cargill, 1987. p.31-61.

EDWARDS, J.W.; CORUZZI, G.M. Photorespiration and light act in concert to regulate the expression of the nuclear gene for chloroplast glutamine synthetase. The Plant Cell, v.1, p.241-248, 1989.

ELLIOTT, W.H. Isolation of glutamine synthetase and glutamotransferase from green peas. Journal of Biological Chemistry, v.201, p. 661-672, 1953. 
ERICSON, M.C. Purification and properties of glutamine synthetase from spinach leaves. Plant Physiology, v.79, p.923-927, 1985.

FAHL, J.L.; CARELLI, M.L.C. Influência do sombreamento nas características fisiológicas envolvidas no crescimento de espécies de coffea. In: SIMPÓSIO INTERNACIONAL SOBRE CAFÉ ADENSADO, Londrina, 1994. Anais. Londrina: IAPAR, 1994. p. 289-290.

FAHL, J.L.; CARELLI, M.L.C.; VEJA, J. et al. Nitrogen and irradiance levels affecting net photosynthesis and growth of Young coffee plants (Coffea arabica L.). Journal of Horticultural Science, v.69, n.1, p.161-169, Jan. 1994

FALEIROS, R.S.S.; MELO, W.J.; CARVALHO, F. et al. Atividade da nitrato redutase e desenvolvimento de mudas de Coffea arabica L. (café). Científica, v.3, p.277-283, 1975.

FARNDEN, K.J.F.; ROBERTSON, J.G. Methods for studing enzymes involved in metabolism related to nitrogenase. In: BERGENSEN, F.J. (Ed.). Methods for evaluating biological nitrogen fixation. New York: John Willey, 1980. p. 265-314.

GALANGAU, F.; DANIEL-VEDELE, F.; MOUREAUX, T. et al. Expression of leaf nitrate reductase gene from tomato and tobacco in relation to light/dark regimes and nitrate supply. Plant Physiology, v. 88, p.383-388, 1988.

GARBAYO, I.; LÉON, R.; VIGARA, J. et al. Inhibition of nitrate consumption by nitriti in entrapped Chlamydomonas reinhardtii cells. Bioresource Technology, v.81, p.207-215, 2002. 
HAGEMAN, R.H.; FLESHER, D. Nitrate reductase activity in corn seedlings as affected by light and nitrate content of nutrient media. Plant Physiology, v.35, n.5, p.700-708, Sept. 1960.

HARPER, J.E.; HAGEMAN, R.H. Canopy and seasonal profiles of nitrate reductase in soybeans (Glycine max L. Merr.). Plant Physiology, v.49, p.146-154, 1972.

HÄUSLER, R.E.; BLACKWELL, R.D.; LEA, P.J. et al. Control of photosynthesis in barley leaves with reduced activities of glutamine synthetase or glutamate synthase: plant characteristics and changes in ammonia, amino acids and nitrate. Planta, v.194, p.406-417, 1994.

HERNANDEZ, A.P.; COCK, J.H.; EL-SHARKAWY, M.A. The responses of leaf gas exchange and stomatal conductance to air humidity in shade-grow coffee, tea, and cacao plants as compared to sunflower. Revista Brasileira de Fisiologia Vegetal, v.1, n.2, p.155-161, 1989.

HEWITT, E.J.; HUCKLESBY, D.P.; NORTON, B.A. Nitrate metabolism. In: BONNER, J.; VARNER, J.E., (Ed.). Plant Biochemistry. New York: Academic Press, 1976. v.20, p.633-681.

HIPKIN, C.R.; AL CHARBI, A.; ROBERTSON, K.P. Studies on nitrate reductase in Britsh angiosperm. II- variation in nitrate reductase activity in natural populations. New Phytologist, v.97, p. 641-651, 1984.

HIREL, B.; WEATHERLEY, C.; CRETIN, C. et al. Multiple subunit composition of chloroplastic glutamine synthetase of Nicotiana tabacum L. Plant Physiology, v.74, p.448-450, 1984. 
HSIAO, T.C. Plant responses to water deficits, efficiency, and drought resistance. Agricultural Meteorology, v.14, p. 59-84, 1979.

HUBER, S.C.; BACHMANN, M.; HUBER, J.L. Post-translational regulation of nitrate reductase activity: a role for $\mathrm{Ca}^{2+}$ and 14-3-3 proteins. Trends in Plant Science, v.1, p. 432-438, 1996.

INSTITUTO BRASILEIRO DO CAFÉ. Cultura do café no Brasil: pequeno manual de recomendações. Rio de Janeiro, 1986. 214p.

JOY, K.W. Ammonia, glutamine and asparagine: a carbon-nitrogen interface. Canadian Journal of Botany, v.66, p.2103-2109, 1988.

KAISER, W.M.; BRENDLE-BEHNISCH, E. Rapid modulation of spinach leaf nitrate reductase activity by photosynthesis. I. Modulation in vivo by $\mathrm{CO}_{2}$ availability. Plant Physiology, v.96, p.363-367, 1991.

KAISER, W.M.; HUBER, S.C. Post-translational regulation of nitrate reductase: mechanism, physiology relevance and environmental triggers. Journal of Experimental Botany, v.52, n.363, p.1981-1989, 2001.

KAISER, W.M.; WEINER, H.; HUBER S.C. Nitrate reductase in higher plants: A case study for transduction of environmental stimuli into control catalytic activity. Physiologia Plantarum, v.105, p. 385-390, 1999.

KOZLOWSKI, T.T.; KRAMER, P.J.; PALLARDY, S.G. The physiological ecology of woody plants, New york: Academic Press, 1991. 657p.

KUMAR, D.; TIESZEN, L.L. Photosynthesis in Coffea arabica: Effects of light and temperature. Experimental Agriculture, v.16, p13-19, 1980. 
KRUG, C.A.; MENDES, J.E.T.; CARVALHO, A. Taxonomia de Coffea arabica L.: descrição das variedades e formas encontradas no Estado de São Paulo. Campinas: Instituto Agronômico, 57p., 1939. (Boletim Técnico, 62).

LAM, H.M.; KOSCHIGANO, K.T.; OLIVEIRA, I.C. et al. The molecular-genetics of nitrogen assimilation into amino acids in higher plants. Annual Review of Plant Physiology and Plant Molecular Biology, v.47, p.569-593, 1996.

LARA, M.; PORTA, H.; PADILLA, J. et al. Heterogeneity of glutamine synthetase polypeptides in Phaseolus vulgaris L. Plant Physiology, v.76, p.1019-1023, 1984.

LEWIS, O.A.M.; WATSON, E.F.; HEWITT, E.J. Determination of nitrate reductase activity in barley leaves and roots. Annals of Botany, v.49, p.3137, 1982. 1982.

McNALLY, S.F.; ORBANJO, T.O.; HIREL, B. et al. Glutamine synthetase isoenzymes of Striga hermonthica and other angiosperm root parasites. Journal of Experimental Botany, v.34, p. 610-614, 1983.

MAESTRI, M.; GOMES, F.R. Crescimento de mudas de café (Coffea arabica L. Var. Bourbon) sob diferentes níveis de luz. Revista Ceres, v.11, n.65, p.265$271,1961$.

MALAVOLTA, E.; VITTI, G.C.; OLIVEIRA, S.A de. Avaliação do estado nutricional das plantas: princípios e aplicações. Piracicaba:POTAFOS, 1989. 201p. 
MARIN, F.R.; SANTIAGO, A.S.; RIGHI, E.Z..; SENTELHAS, P.C.; ANGELOCCI, L.R.; MAGGIOTTO, S.R.; PEZZOPANE, J.R.M. Solar radiation interception and its relation with transpiration in different coffee canopy layers. Revista Brasileira de Agrometeorologia, v.11, n1, p.1-6. 2003.

MATT, P.; GEIGER, M.; WALCH - LIU, P. et al. Elevated carbon dioxide increases nitrate uptake and nitrate reductase activity when tobacco is growing on nitrate, but increases ammonium uptake and inhibits nitrate reductase activity when tobacco is growing on ammonium nitrate. Plant, Cell and Environment, v. 24, p 1119-1137, 2001.

McNALLY, S.F.; ORBANJO, T.O.; HIREL, B. et al. Glutamine synthetase isoenzymes of Striga hermonthica and other angiosperm root parasites. Journal of Experimental Botany, v.34, p. 610-614, 1983.

MENDEL, R.R.; STALLMEYER, B. Molybdenum cofactor (nitrate reductase) byosynthesis in plants: First molecular analysis. In: INTERNATIONAL CONGRESS ON PLANT TISSUE AND CELL CULTURE, 8., Florence, 1994. Current plant science and biotechnology:proceedings. Kluwer, Dordrecht: Netherlands, 1995. p.577-582.

MIFLIN, B.J.; LEA, P.J. Ammonia assimilation. In: STUMPF, P.K.; CONN, E.E. (Ed.). The biochemistry of plants. London: Academic Press, 1980. v.5, p.169-202.

MIFLIN, B.J.; WALLSGROVE, R.M.; LEA, P.J. Glutamine metabolism in higher plants. Current Topics Cellular Regulation, v.20, n.1, p.1-43, 1981. 
MIRANDA NETO, A.T. de. Assimilação do azoto em mudas de café (Coffea arabica L.) culativadas sob diferentes níveis de sombra e formas de azoto. Viçosa, 1970. 38p. Dissertação (M.S.) - Universidade Federal de Viçosa.

OAKS, A. Primary nitrogen assimilation in higher plants and its regulation. Canadian Journal of Botany, v.72, p.739-750, 1994.

PAIVA, L.C. Produção de mudas de cafeeiro (Coffea arabica L.) em diferentes níveis de sombreamento e seus reflexos na implantação. Lavras, 2001. 61p. Dissertação (M.S.) - Universidade Federal de Lavras.

PROVAN, F.; LILLO, C. Photosynthetic post translational activation of nitrate reductase. Journal of Plant Physiology, v. 154, p. 605-609, 1999.

PUJAD-RENAUD, V.; CLEMENT, A.; PERROT-RECHENMANN, C. Ethyleneinduced increase in glutamine synthetase activity and mRNA levels in Hevea brasiliensis latex cells. Plant Physiology, v.105, n.1, p.127-132, May 1994.

QUEIROZ, C.G.S.; RENA, A.B.; CORDEIRO, A.T.; ALVES, J.D. Ritmo diurno na atividade da redutase de nitrato em folhas e raízes de Coffea arabica $\mathrm{L}$. Pesquisa Agropecuária Brasileira, v.28, p.787-795, jul. 1993.

QUEIROZ, C.G.S.; ALVES, J.D.; RENA, A.B. et al. Efeito do cloranfenicol, propanol, $\mathrm{pH}$ e temperatura sobre a atividade in vivo da redutase de nitrato em cafeeiros jovens. Revista Brasileira de Botânica, v.14, p.73-77, 1991.

ROBERT, F.M.; WONG, P.P. Isoenzymes of glutamine synthetase in Phaseolus vulgaris L. and Phaseolus lunatus L. root nodules. Plant Physiology, v. 81, p.142-148, 1986. 
ROTH, R.; HALL, L.N.; BRUTNELL, T. P. et al. Bundle sheath defective2, a mutation that disrupts the coordinated development of bundle sheath and mesophyll cells in maize leaf. The Plant Cell, v. 8, p. 915-927, 1996.

RUFTY, B.; THOMAS, J.E.; REMMLER, J.L. et al. Intracellular localization of nitrate reductase in roots. Plant Physiology, v.82, p.675-680, 1986.

SCHEIBLE, W-R.; GONZÁLES-FONTES, A.; LAUERER, M. et al. Nitrate acts as a signal to introduce organic acid metabolism and repress starch metabolism in tobacco. The Plant Cell, v.9, p.783-798, 1997.

SILVEIRA, A.J.; MAESTRI, M. Crescimento de mudas de café (Coffea arábica L. cv Bourbon) sob quatro níveis de luz, em Viçosa, Minas Gerais. Revista Ceres, v.20, n.111, p.354-369, set./out. 1973

SOLOMONSON, L. P.; BARBER, M.J. Assimilatory nitrate reductase: functional properties and regulation. Annual Review of Plant Physiology and Plant Molecular Biology, v.41, p.225-253, 1990.

SOUZA, D.M.G.; LOBATO, E. Adubação com nitrógeno. In: SOUZA, D.M.G.; LOBATO, L (Ed.). Cerrado: correção do solo e adubação. Planaltina: Embrapa Cerrados, 2002. p.129-145.

STITT, M. Frutose-2, 6-biphosphate and carbohydrate metabolism. Plant Physiology, v.84, p.202-204, 1987.

STITT, M.; MÜLLER, C.; MATT, P. et al. Steps towards an integrated view of nitrogen metabolism. Journal of Experimental Botany, v.53, n.370, p.959970, 2002. 
SYLVAIN, P. Some observations on Coffea arabica L. in Ethiopia. Turrialba, v.5, p.37-53, 1955.

SUMAR, N.; CASSELTON, P.J.; McNALLY, S.F.; STEWART, G.L. Occurrence of isoenzymes of glutamine synthetase in Chlorella kessleri. Plant Physiology, v.74, p. 204-207, 1984.

TAIZ, L.; ZIEGER, E. Plant Physiology. California: The Benjamim/Cummings, 1998. 792p.

TALBOTT, L.D.; ZEIGER, E. The role of sucrose in guard cell osmoregulation. Journal of Experimental Botany, v.49, p.329-337. 1998.

TEMPLE, S.J.; VANCE, C.P.; GANT, J.S. Glutamate synthase and nitrogen assimilation. Trends in Plant Science, v.3, p.51-56, 1998.

THOMAZIELLO, R.A.; OLIVEIRA, E.G.; TOLEDO FILHO, J.A. et al. Cultura do café. Campinas: Coordenadoria da Assistência Técnica Integral, 1996. 75p. (CATI. Boletim Técnico, 193).

TJADEN, G.; EDWARDS, J.W.; CORUZZI, G.M. cis elements and trans-acting factors affecting regulation of a non-photosynthetic light-regulated gene for chloroplast glutamine synthetase. Plant Physiology, v. 108, p.1109-1117, 1995.

VAUGHN, K.C.; CAMPBELL, W.H. Immunogold localization of nitrate reductase in maize leaves. Plant Physiology, v.88, p.1354-1357, 1988. 
VINCENTZ, M.; MOUREAUX, T.; LEYDECKER, M.T. et al. Regulation of nitrate and nitrite reductase expression in Nicotiana plumbaginifolia leaves by nitrogen and carbon metabolites. The Plant Journal, v.3, p.313-324, 1993.

WALLSGROVE, R.M.; TURNER, J.C.; HALL, N.P. et al. Barley mutants lacking chloroplast glutamine synthetase-biochemical and genetics analyses. Plant Physiology, v. 83, p.155-158, 1987.

WOOLFOLK, C. A.; STADTMAN, E.R. Cumulative feedback inhibition in the multiple and product regulation of glutamine synthetase activity in Escherichia coli. Biochemical and Biophysical Research Communications, v.17, n.4, p.313-319, 1964.

YANEVA, I. A.; BAYDANOVA, V. D.; VUNKOVA-RADEVA, R. V. Nitrate reductase activation state in leaves of molybdenum-deficient winter wheat. Journal of Plant Physiology, v.157, p.495-501, 2000. 